\title{
A Burkean Perspective on Patent ELIGIBILITY
}

By Thomas F. Cotter ${ }^{+}$

\section{TABle of ConTENTS}

I. INTRODUCTION .855

II. PATENT EligibILity

III. SOME BURKEAN-INSPIRED OBJECTIONS TO THE CONTEMPORARY TREND .

IV. SOME MODEST STEPS TOWARD REFORM …………..................884

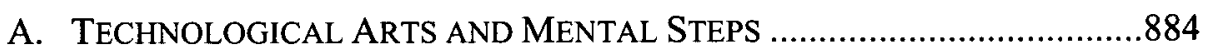

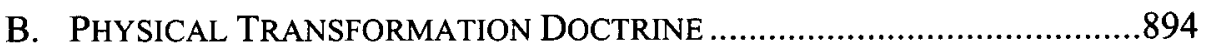

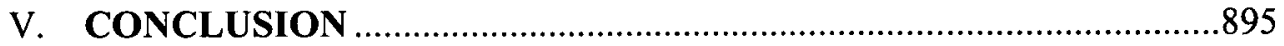

\section{INTRODUCTION}

I doubt that the Anglo-Irish statesman and political theorist Edmund Burke devoted a great deal of attention to patent law. ${ }^{1}$ To be sure, patents

(C) 2007 Thomas F. Cotter

$\dagger$ Professor of Law, University of Minnesota Law School. I presented this Article at the George Washington University Law School/Oracle Corporation symposium, titled "What's Ahead on Highway 101?" held at the George Washington University Law School on November 3, 2006. I thank Oracle Corporation for its generous financial support; the conference organizers for their graciousness in inviting me to participate in the conference; and the conference participants and attendees, in particular Martin Adelman, Shamnad Basheer, Chris Cotropia, John Duffy, the Honorable Michael Fleming, Sean O'Connor, Kristen Osenga, the Honorable Randall Rader, Joshua Sarnoff, Richard Stern, and John Witherspoon, for their comments and criticism. I also thank, for their comments and criticism, Kevin Collins and Alan Durham; Sharada Devarasetty, for research assistance; and Dale Carpenter, for his helpful insights into the thought of Edmund Burke. All opinions expressed herein, as well as any errors, are mine alone.

1. The only evidence I have seen thus far of Burke's thoughts on patents is a citation to an unpublished manuscript of Burke's that is said to be in the National Library of Ireland. See David L. Cohen, Article 69 and European Patent Integration, 92 Nw. U. L. REV. 1082, 1095 n.63 (1998) (citing KEITH DUTTON, EDMUND BURKE 23 (1979) (quoting Edmund Burke for the proposition that " $[\mathrm{m}]$ onopoly is an odious term ... [but patent] is 
for new inventions were part of the legal environment during Burke's lifetime (1729-1797), both within the United Kingdom and in several other countries, including (from 1790 on) the United States. ${ }^{2}$ But Burke had many other matters to occupy his attention, among them the American colonists' revolt (Burke favored a conciliatory approach), Catholic emancipation (which Burke also favored), and the mismanagement of the East India Company (the governor of which Burke unsuccessfully prosecuted for corruption). Burke is probably best remembered today, however, for his passionate defense of traditional conservatism, most prominently in his famous work Reflections on the Revolution in France. ${ }^{3}$

Written following the deposition of Louis XVI and the establishment of the French Republic, but before Louis's execution and the Reign of Terror, Reflections casts the revolution in a sinister light, arguing that the radical changes convulsing France at the time were likely to bring considerable misery in their wake. In making his case against the revolution, Burke presents an eloquent defense of tradition and custom that has attracted many adherents to the present day. In what is probably the most oft-quoted passage from the book, Burke expresses fear over "put[ting] men to live and trade each on his own private stock of reason; because we suspect that this stock in each man is small, and that the individuals would do better to avail themselves of the general bank and capital of nations and

not making a monopoly of what was common. It is the direct reverse, for the condition of the patent, compelling a discovery, makes that common which was private before")); $c f$. Justin Hughes, The Philosophy of Intellectual Property, 77 GEO. L.J. 287, 291 (1988) (speculating that Burke would have objected to the "egalitarian" nature of intellectual property, which empowers "the talented upstarts Burke sought to restrain").

2. As explained by historian Christine MacLeod, however, to refer to English practice during Burke's day as a patent "system" may be "something of a misnomer." CHRISTINE MACLEOD, INVENTING THE INDUSTRIAL REVOlution: THE ENGlish PATENT SysTEM, 1660-1800 1 (1988). Although "[p]atents for invention have been granted regularly since the middle of the sixteenth century ... it was not until 1852 that the first major legislation on patents was enacted by parliament and the Patent Office established." Id. Prior to that time, the inventor had to endure a circuitous ten-stage procedure involving several different government offices. See id. at 40-41. For discussion of the early U.S. patent system, see EdWARd C. WALTERSCHEID, TO Promote THE Progress of USEFUl ARTS: AMERICAN PATENT LAW AND ADMINISTRATION 1798-1836(1998).

3. See EDMUND BuRKe, ReFlections on the REVOlution In FRANCE (Frank M. Turner ed., Yale Univ. Press 2003) (1790). Burke actually was a member of the Whig Party, not the Tories, and at least some of his modern day admirers depict him as something of a moderate liberal within the context of his time and place. See CONOR CRUISE O'Brien, The Great Melody: A Thematic BIograPhy and COMMENTEd ANTHOlogy OF EDMUND BURKE xxxii-xli, lxi-lxiv (1992); Carl Bogus, Rescuing Burke, 72 Mo. L. REV. (forthcoming 2007) (distinguishing Burke from modern-day religious conservatives, neoconservatives, and libertarians). 
of ages." ${ }^{4}$ In other words, for Burke, tradition and custom embody practices that incorporate the collective insights of many people and that have proven successful over time; they are therefore likely to reflect more wisdom and foresight than any one individual is likely to possess. Indeed, much of the value of tradition and custom may not even be apparent to any single individual or subgroup. The many are indeed smarter than the few.

Burkean conservatism nevertheless labors under some obvious limitations. More than a few traditional practices, such as slavery or torture, surely strike most of us as downright repellent. ${ }^{5}$ Moreover, the extent to which tradition reflects the perspectives of elites clearly presents a bone of contention for thinkers more inclined towards egalitarianism. On a more practical level, one might question whether tradition can respond adequately to emergencies or to novel, long-term challenges such as environmental degradation. But Burke himself recognized that change is sometimes necessary to respond to changing circumstances, and that mindless conformity to tradition is no virtue. As Burke put it, "A state without the means of some change is without the means of its conservation." ${ }^{\text {"B }}$ Burkean conservatives nevertheless clearly prefer gradual, incremental change to radical change, anticipating that radical change can give rise to unforeseeable negative consequences and erode the unappreciated benefits embodied in tradition. ${ }^{7}$ For Burkeans, changes to laws and social practices should be based whenever possible on experience, as opposed to abstract ideas, and should be proportionate to the perceived change in circumstances. $^{8}$

4. BURKE, supra note 3 , at 74 .

5. See Roger Scruton, The Meaning of Conservatism 34 (1999) (stating that the traditions which conservatives uphold, unlike torture, "engage the loyalty of their participants, in the deep sense of moulding their idea of what they are and should be"); Cass Sunstein, Burkean Minimalism, $105 \mathrm{MICH}$. L. REV. 353, 371 (2006) (arguing that Burkeanism fails when custom is based on collective action or other problems, and thus fails to reflect latent wisdom). Burke himself was opposed to slavery. See O'BRIEN, supra note 3, at 91-92; Bogus, supra note 3.

6. BURKE, supra note 3, at 19.

7. See id. at 51-52, 133, 143.

8. There are, to be sure, many (sometimes conflicting) interpretations of Burkean conservatism. Some self-professed Burkeans, such as Russell Kirk and Roger Scruton, emphasize tradition's role in affirming the meaning of individual lives within the context of civil and religious society. See RUSSELl KIRK, The Conservative Mind: From BURKE TO ELIOT 28-47 (7th ed. 1986); SCRUTON, supra note 5, at 8, 30-36, 157-63. By contrast, Friedrich Hayek admired Burke's appreciation of tradition as an aggregator of individual wisdom, and identified Burke as a classical "liberal" in the sense of a defender of free markets and limited government. See F.A. Hayek, Why I Am Not a Conservative, in The CONSTITUTION OF LIBERTY 397, 407-08 (1960); see also F.A. HAYEK, THE FATAL 
It would be strange, no doubt, to argue that Burke's views on such specific and weighty matters as the French Revolution, the British Constitution, or the relationship of church to state have any direct bearing on, of all things, patent law. What I will argue in this Article, however, is that some of the general themes found in Burke's writing-his preference for gradual, incremental, organic social change, as opposed to top-down, grandly theoretical social engineering, as well as his concomitant appreciation for the unarticulated wisdom that is sometimes embodied in tradition-may shed some light on some contemporary debates about the scope of patentable subject matter. To be sure, the content of these contemporary debates may pale in comparison with the political and social upheavals that motivated Burke to record his thoughts for posterity. But the scope of patent law is hardly a trivial matter either, and a well-functioning patent system can play a crucial role in either fostering or impeding the innovation upon which human survival may depend. I will argue that a Burkeaninspired approach to patent law-one that respects, though it does not worship, tradition and that generally prefers gradual to radical changesuggests that we consider again some traditional, but now dormant, restraints on patentable subject matter that may have embodied a degree of wisdom. More specifically, I argue that some of the traditional limitations on patentable subject matter, as embodied in the technological arts, mental steps, and physical transformation doctrines, may yet have much to recommend them. Reintroduction of these requirements, suitably reformed to

CONCEIT: THE ERRORS OF SOCIALISM 7 (1988) (arguing that free markets aggregate information concerning consumer demand much more efficiently than any central planner ever could). Michael Oakeshott, on the other hand, found affinity in Burke's admiration of custom as embodying practical wisdom that cannot be reduced to mere technique, and dismissed Hayek's rationalist politics as the mirror image of the trend it sought to counter. See Michael OAKeshotT, Rationalism IN POLITICS AND OTHER ESSAYS 26 (Liberty Press 1991). To the extent my discussion above emphasizes tradition as the embodiment of unappreciated wisdom, it may have more in common with the Hayek and Oakeshott interpretations than with those of Kirk and Scruton.

There are also different ways that Burkeans might define and use tradition. As Sunstein notes, with particular emphasis on the application of Burkeanism to constitutional adjudication, some Burkeans might stress adherence to social practices while others might emphasize adherence to judicial precedent (and Burke himself tended to conflate the two); some might look to tradition at a high level of abstraction while others might focus more narrowly on the content of specific traditions. See Sunstein, supra note 5 , at 368 . For present purposes, my modest claim is simply that certain patent law doctrines such as technological arts, mental steps, and physical transformation, embodied a tradition loosely understood as a general or common understanding of the limited scope of patentable subject matter; and that that general or common understanding, whatever its flaws may have been, may also have embodied a degree of wisdom that is too easily shunted aside in the quest for an all-encompassing approach to patentable subject matter. 
reflect changing times, into U.S. law would permit the patenting of software-related inventions and business methods, as is arguably required under the TRIPs Agreement. ${ }^{9}$ But, it might go a long way toward screening out patents that read on laws of nature or that threaten to interfere with important liberty interests.

Part II of this Article presents an overview of patent eligibility and discusses the courts' and the U.S. Patent and Trademark Office's (USPTO) retreat from the technological arts, mental steps, and physical transformation doctrines. Part III argues that these traditional limitations may have embodied some underappreciated wisdom. Part IV suggests some possible ways in which these doctrines might be revived and reformed to be of use today. Part V concludes.

\section{PATENT ELIGIBILITY}

The current version of the Patent Act explicitly refers to four broad categories of patentable subject matter, namely processes, machines, articles of manufacture, and compositions of matter. ${ }^{10}$ Earlier versions, though worded slightly differently, ${ }^{11}$ were interpreted for the most part to include these same four categories, although until the mid-nineteenth century it was unclear whether processes were patentable to the extent they read on embodiments not disclosed within the patent description. ${ }^{12}$ No version of the Act, however, has ever defined these terms or stated what types of inventions or discoveries fall outside the scope of statutory subject matter. ${ }^{13}$ Courts and commentators nevertheless have traditionally agreed upon three general categories of nonpatentable subject matter,

9. See Agreement on Trade-Related Aspects of Intellectual Property Rights, Apr. 15, 1994, Marrakesh Agreement Establishing the World Trade Organization, Annex 1C, Legal Instruments-Results of the Uruguay Round vol. 31, 33 I.L.M. 1197 (1994) [hereinafter TRIPs Agreement].

10. 35 U.S.C. $\S 101$ (2000).

11. See, e.g., Patent Act of 1870 , ch. 230, § 24, 16 Stat. 198, 201 ("[A]ny person who has invented or discovered any new and useful art, machine, manufacture, or composition of matter ... may ... obtain a patent therefor."); Patent Act of 1793, ch. 11, 1 , 1 Stat. 318, 319 (stating the same language as the Patent Act of 1870).

12. See, e.g., 1 R. CARL MOY, MOY'S WALKER ON PATENTS $\S \S 5.21-.22$ (4th ed. 2006) (discussing doctrinal developments).

13. Case law has sometimes provided definitions of the terms "machine," "composition of matter," "manufacture," and "process." See, e.g., Diamond v. Diehr, 450 U.S. 175, $182-84$ (1981) (discussing processes); Diamond v. Chakrabarty, 447 U.S. 303, 308 (1980) (discussing articles of manufacture and compositions of matter). For present purposes, not much hangs on the distinctions among machines, compositions of matter, and manufactures. As for processes, see infra note 39 and accompanying text. 
namely laws of nature, abstract ideas, and naturally-occurring physical phenomena. ${ }^{14}$ These three exclusions from the scope of patentable subject matter persist, but several other doctrines that courts once employed to exclude yet other inventions from patent eligibility have in recent years been narrowed or jettisoned altogether. Prominent among these other exclusions have been the mental steps doctrine, the technological arts doctrine, and (though it is not the principal focus of this Article) the exclusion of business methods, though there have been others. ${ }^{15}$

The basic intuition behind the mental steps doctrine-that patent claims should not "read on" (cover) activity that takes place within the human mind-appears to underlie several decisions dating back to the early twentieth century. ${ }^{16}$ But the doctrine has always been somewhat am-

14. See Diehr, 450 U.S. at 185; Chakrabarty, 447 U.S. at 309 . Some critics have argued, however, that the U.S. Supreme Court has never squarely held that laws of nature are not patentable, and that cases that assert, or have been cited as having asserted, this principle do so only in dicta. See, e.g., Brief for Franklin Pierce Law Center as Amicus Curiae Supporting Respondents at 6-11, Lab. Corp. of Am. Holdings v. Metabolite Labs., Inc., 126 S. Ct. 2921 (2006) (No. 04-607), 2006 WL 304561. It is nevertheless fair to state that the vast majority of observers, including the Patent Office itself, have long interpreted laws of nature, abstract ideas, and naturally-occurring physical phenomena as unpatentable. Products of nature that have been isolated and refined from their naturallyoccurring state, however, have been viewed as patentable at least since Parke-Davis \& Co. v. H.K. Mulford Co., 189 F. 95, 103 (S.D.N.Y. 1911), aff'd in part, rev'd in part on other grounds, 196 F. 496 (2d Cir. 1912). The Supreme Court established the patentability of human-created bacterium in Chakrabarty, 447 U.S. at 310 . Although critics of Chakrabarty contend, with some force, that this interpretation of the Patent Act departed from the traditional understanding of the scope of patentable subject matter, my principal focus in this Article is on departures involving inventions other than life forms.

15. For example, beginning in the mid-nineteenth century, the USPTO and the courts began rejecting applications claiming purportedly novel types of business forms under the "printed matter" doctrine. By most accounts, the doctrine was intended to preserve the boundary between patent and copyright law. See, e.g., MoY, supra note 12, $\S \S 5.10-5.11$. As the doctrine exists today, it renders unpatentable an invention that is distinct from the prior art only by virtue of printed matter that is not "functionally related to the underlying object." See In re Ngai, 367 F.3d 1336, 1338 (Fed. Cir. 2004). Construed more broadly, the printed matter doctrine might pose a serious threat to the patentability of many software-related inventions, but few observers, even among those most critical of software patents, argue for revival of a strengthened printed matter doctrine.

16. See Don Lee, Inc. v. Walker, 61 F.2d 58, 67 (9th Cir. 1932) (rejecting a claim directed toward a method of computation); Ex parte Meinhardt, 1907 Comm'n Dec. 238, 239 (stating that methods for solving mathematical problems are unpatentable); Warren T. Jessup, Patentability of Mental Processes, 40 J. PAT. OFF. SOC'Y 482, 482 (1958) (describing the doctrine as having evolved during the preceding fifty years, though in the author's opinion on the basis of a misreading of case law as requiring that processes effect physical transformations); Norman D. McClaskey, The Mental Process Doctrine: Its 
biguous in its interpretation. A very broad interpretation of the doctrine would render unpatentable a process that contains any steps that can be performed mentally, regardless of whether (1) the process also contains steps that are incapable of being performed mentally, or (2) the steps that can be performed mentally also can be performed non-mentally. It does not appear that any courts or commentators have ever interpreted the doctrine quite this expansively, although some appear to have taken the position that subject matter is unpatentable if the novelty or nonobviousness of the invention is attributable entirely to the mental step or steps (the socalled "point of novelty" test) ${ }^{17}$ Some observers also expressed the view that a process that can be performed entirely by mental steps is unpatentable, even if the process also can be performed by means of a machine or apparatus. ${ }^{18}$ The narrowest interpretation of the doctrine would limit patent exclusion to processes that are incapable of being performed by a machine or apparatus - that is, to processes which, if they are to be performed at all, must be performed exclusively by mental steps. ${ }^{19}$

Origin, Legal Bases, and Scope, 55 IOWA L. REV. 1148 (1970) (similar); Katharine P. Ambrose, Comment, The Mental Steps Doctrine, 48 TENN. L. REV. 903, 903 (1981) (referring to the doctrine as "the product of some unclear thinking in the 1940s"). Interestingly, though, Ambrose concludes her critical analysis of the mental steps doctrine by proposing that a process would lack novelty if it attempted "to remove from the public domain any abstract idea, law of nature, or physical phenomenon that is presumed to have always existed." Id. at 917. This is not very different from Professor Collins' proposal, discussed infra notes 186-191 and accompanying text, that the mental steps doctrine be revived to preclude patenting of claims which depart from the prior art only by virtue of their inclusion of a mental step, on the ground that such claims do remove subject matter from the public domain.

17. See In re Abrams, 188 F.2d 165, 169 (C.C.P.A. 1951); In re Heritage, 150 F.2d 554, 556-57 (C.C.P.A. 1945); see also 1 Donald S. Chisum, Chisum ON PATENTS $\S 1.03[6]$ (2006) (describing the "basic idea" of the mental steps doctrine as being "that no patent can be obtained for a method an essential component of which consists of human mental participation").

18. See In re Mahony, 421 F.2d 742, 745 (C.C.P.A. 1970) (noting that "both sides ... have assumed that if a claim reads on both mental and non-mental implementation of a process, the claim is drawn to non-statutory subject matter," but expressly declining to decide whether that interpretation of the doctrine was correct); MoY, supra note 12, $\S 5.40$ (stating that "[i]nventions claimed so narrowly as to cover only implementation by machine are exempt" from the mental steps doctrine).

19. To cite a completely hypothetical example, presumably a claim could be drafted in such a way as to specify that some or all of its steps must be performed mentally by a human being, such as a method for performing a mind-reading illusion. A claim that permits too much individual discretion or variability in its performance, however-for example, a claim that depends upon the exercise of subjective aesthetic judgmentprobably would fail for lack of definiteness, regardless of the existence or not of a mental 
In In re Musgrave, ${ }^{20}$ the inventor sought to patent a method for more accurately mapping subsurface formations in the earth's crust. Some of the steps of the method involved correcting for errors attributable to the presence of topsoil and the distance from shotpoint to measuring stations. ${ }^{21}$ The patent examiner had rejected the claims at issue on the ground that they included steps that could be performed mentally, but the Court of Customs and Patent Appeals reversed. ${ }^{22}$ In so holding, the court rejected the point of novelty test, reasoning that "novelty and advancement of an art are irrelevant to a determination of whether the nature of a process is such that it is encompassed by the meaning of 'process' in 35 U.S.C. $101 ., 23$ In addition, the court rejected all but the narrowest interpretation of the mental steps doctrine ${ }^{24}$ and called into doubt even this interpretation by stating that "[a]ll that is necessary ... to make a sequence of operational steps a statutory process within 35 U.S.C. 101 is that it be in the technological arts so as to be in consonance with the Constitutional purpose to promote the progress of "useful arts.",25 As predicted by the concurring judge in Musgrave, who accused the majority of a radical break with precedent, ${ }^{26}$ the mental steps doctrine has become largely a dead letter ever since. ${ }^{27}$

Yet, while the Musgrave court narrowed the mental steps doctrine to near oblivion, it nevertheless referred, in the portion of the opinion quoted above, to the necessity for a patentable process to "be in the technological arts so as to be in consonance with the Constitutional purpose to promote the progress of "useful arts." ${ }^{28}$ But this "technological arts" doctrine too

steps doctrine. See Datamize, L.L.C. v. Plumtree Software, Inc., 417 F.3d 1342, 1350 (Fed. Cir. 2005); In re Prater, 415 F.2d 1393, 1402 n.22 (C.C.P.A. 1969).

20. 431 F. $2 \mathrm{~d} 882$ (C.C.P.A. 1970).

21. See id. at $882-85$.

22. See id. at 885-93.

23. Id. at 889; see also In re Bernhart, 417 F.2d 1395, 1399 (C.C.P.A. 1969) (rejecting point of novelty).

24. See Musgrave, 431 F.2d at 893.

25. $I d$.

26. See id. at 893-94 (Baldwin, J., concurring). Judge Baldwin concluded, however, that the claims at issue either read only on machine-implemented steps, or included steps that were not "purely mental," and therefore they did not violate the mental steps doctrine. See id. at 895.

27. See Kevin Emerson Collins, Propertizing Thought 53 (unpublished manuscript, on file with author).

28. Musgrave, 431 F.2d at 893. The author of the majority opinion in Musgrave, Judge Giles Rich, was one of the drafters of the 1952 Patent Act. See A. Samuel Oddi, Regeneration in American Patent Law: Statutory Subject Matter, 46 IDEA 491, 546 (2006). He was also the author of the majority opinions in Alappat and State Street Bank, 
has recently fallen by the wayside, as a consequence of the expansion of patentable subject matter over the last twenty-five years-an expansion that in large part has been driven by the evolving standards relating to the patentability of computer-related art.

The first two times the U.S. Supreme Court took up the issue of the patentability of computer-related art, in Gottschalk v. Benson ${ }^{29}$ and Parker v. Flook, ${ }^{30}$ it appeared to take a relatively hardline position against the patentability of these inventions. In both cases, the majority noted that one can characterize computer programs as mathematical algorithms, and suggested that such algorithms are akin to laws of nature and therefore nonpatentable. ${ }^{31}$ Both cases also purported not to hold, however, that computer-related art is per se unpatentable, ${ }^{32}$ and (whether wittingly or not) suggested several ways in which future courts might limit their holdings. For example, in Gottschalk the Court noted that the claims at issue "were not limited to any particular art or technology, [or] to any particular appa-

discussed infra at text accompanying notes 44-69. It is notable therefore that, even for Judge Rich, the scope of patentable subject matter was not necessarily coextensive with merely the "useful, concrete, and tangible," unless the latter two opinions illustrate a change in his views. For Judge Rich, patentable subject matter must pertain to the "useful" or "technological" arts, in contrast with the "liberal arts" or "fine arts." See John R. Thomas, The Post-Industrial Patent System, 10 Fordham InTEll. Prop. MEdia \& ENTER. L.J. 3, 9 n.35 (1999) (explaining that not every invention is patentable because "[i]nvaluable though it may be to individuals, the public, and national defense, the invention of a more effective organization of the materials in, and the techniques of teaching a course in physics, chemistry or Russian is not a patentable invention" and noting further that "[a]lso outside that group is one of the greatest inventions of our times, the diaper service" (quoting Giles S. Rich, Principles of Patentability, 28 GEO. WASH. L. REV. 393, 393-94 (1960))).

29. 409 U.S. 63 (1972). Justice Douglas authored the opinion of the Court. There were no dissents, but three justices (Stewart, Blackmun, and Powell) did not participate in the case.

30. 437 U.S. 584 (1978). Justice Stevens authored the majority opinion. Justice Stewart dissented, and was joined by Chief Justice Burger and by Justice Rehnquist. See id. at 599 (Stewart, J., dissenting) (arguing that the process at issue did not "lose[ ] its status of subject-matter patentability simply because one step in the process would not be patentable subject matter if considered in isolation").

31. See id. at 589 (stating that "an algorithm, or mathematical formula, is like a law of nature"); Gottschalk, 409 U.S. at 65, 67-68 (describing the invention at issue as an "algorithm," that is, "a [p]rocedure for solving a given type of mathematical problem," and likening algorithms to nonpatentable "phenomena of nature, ... mental processes, and abstract intellectual concepts").

32. See Flook, 437 U.S. at 590 ("[A] process is not unpatentable simply because it contains a law of nature or a mathematical algorithm."); Gottschalk, 409 U.S. at 71 ("It is said that the decision precludes a patent for any program servicing a computer. We do not so hold."). 
ratus or machinery, or to any particular end use"; and that the claims "purported to cover any use of the claimed method," for converting binarycoded decimal numerals into pure binary numbers, using a general purpose digital-purpose computer. ${ }^{33}$ As a result, "the patent would wholly pre-empt the mathematical formula and in practical effect would be a patent on the algorithm itself." 34 Similarly, in Flook the Court stated that "a process is not unpatentable simply because it contains a law of nature or a mathematical algorithm." "35 But the Court in Flook nevertheless held that the invention at issue, a method for updating "alarm limits" in connection with catalytic conversion, was unpatentable - despite the fact that a patent would not have precluded all uses of the underlying algorithm and that the claims included the post-solution step of adjusting the alarm value to the updated number calculated by use of the algorithm (because the postsolution step was "conventional or obvious"). ${ }^{36}$

Four years later, however, the Court reversed course in Diamond $v$. Diehr. ${ }^{37}$ At issue in Diehr was the patentability of a process for curing rubber, using a computer to repeatedly calculate an algorithm, the Arrhenius equation, that is useful for determining the appropriate cure time and that had long been known in the art. ${ }^{38}$ This time, the Court viewed the invention at issue as unequivocally a statutory (i.e., potentially patentable) "process." Quoting the Court's 1877 decision in Cochrane v. Deener, the Court defined a process as "a mode of treatment of certain materials to produce a given result," "an act, or a series of acts, performed upon the subject-matter to be transformed and reduced to a different state or thing." ${ }^{39}$ (As we shall see, the question of whether a statutory process must effect a physical transformation-and if so, exactly what this

33. Gottschalk, 409 U.S. at 64.

34. Id. at 72 .

35. Flook, 437 U.S. at 590.

36. Id. The Court noted the Patent Board of Appeals' application of a "point of novelty" test, under which the patent eligibility of a process depends on the patentability of the step or steps that are distinct from the prior art. See id. at 587-88. It purported not to apply that test itself, stating that the Court's approach is "not at all inconsistent with the view that a patent claim must be considered as a whole," but rather reflects the fact that there was no inventive concept in the application other than the algorithm. Id. at 593-94.

37. 450 U.S. 175 (1982). Justice Rehnquist authored the 5-4 majority opinion of the Court. Justice Stevens dissented and was joined by Justices Brennan, Marshall, and Blackmun. See id. at 193.

38. See id. at 177-78.

39. Id. at 183 (quoting Cochrane v. Deener, 94 U.S. 780, 787-88 (1877)); see also id. at 184 (describing the invention at issue as "a physical and chemical process for molding precision synthetic rubber products," involving the transformation of raw materials into a different state or thing). 
means - or whether the quotation from Cochrane is merely illustrative of one type of statutory process, remains controversial.) The Court reasoned that the invention was not rendered non-statutory merely by virtue of the fact that several of its steps employed a mathematical equation and a computer, and noted that those claims did not preempt all uses of the Arrhenius equation. ${ }^{40}$ And while the Court restated the Flook propositions that mathematical principles by themselves are unpatentable, and that "insignificant post-solution activity will not transform an unpatentable principle into a patentable process," concluding that the invention at issue was unpatentable because all of the steps other than the use of the computer were known in the $\operatorname{art}^{42}$-thus arguably laying to rest the point of novelty test.

In the years immediately following Diehr, the fledgling United States Court of Appeals for the Federal Circuit struggled to interpret the standards announced in Diehr with respect to the patentability of computerrelated art. ${ }^{43}$ In the landmark case of In re Alappat, the Federal Circuit, sitting en banc, articulated an expansive scope of patent eligibility for computer-related art. ${ }^{44}$ In Alappat the inventor claimed as his invention a machine that, when programmed to perform an algorithm he had developed, would improve the electronic waveform displayed on a digital oscilloscope. ${ }^{45}$ The USPTO had rejected the claims, reasoning that an invention claiming a computer programmed to perform a series of calculations and output data was indistinguishable from an unpatentable mathematical algorithm. ${ }^{46}$ The Federal Circuit, however, reversed on the ground that Alappat's invention fell within the statutory category of a "machine." ${ }^{47}$ In so holding, the court cited the Supreme Court's opinion in Diamond $v$. Chakrabarty-which held that human-created life forms constitute patentable subject matter-for the proposition that Congress intended $\S 101$ to encompass any new and useful process, machine, manufacture, or com-

40. See id. at 187.

41. Id. at 191-92.

42. See id. at $188-89$. The Court stated that the questions of whether the invention was novel and whether it was nonobvious were separate from the question of whether the invention fell within the scope of patentable subject matter. See id. at 190.

43. See, e.g., Arrhythmia Res. Tech., Inc. v. Corazonix Corp., 958 F.2d 1053 (Fed. Cir. 1992); In re Iwahashi, 888 F.2d 1370 (Fed. Cir. 1989); see also In re Abele, 684 F.2d 982 (C.C.A.P. 1982).

44. In re Alappat, 33 F.3d 1526, 1542 (Fed. Cir. 1994) (en banc).

45. See id. at 1537.

46. See id. at 1539.

47. See id. at 1544. 
position of matter that satisfied all of the other statutory criteria. ${ }^{48}$ The court did not read the Supreme Court's trilogy of computer-related art cases as establishing an "overly broad, fourth category of subject matter excluded from $\S 101, " 49$ and instead interpreted those cases as standing for the proposition that "certain types of mathematical subject matter, standing alone, represent nothing more than abstract ideas until reduced to some type of practical application." ${ }^{50}$ Thus, the proper focus is on whether the claim as a whole recites patentable subject matter, and not whether it contains some elements that would be unpatentable by themselves. ${ }^{51}$ Applying these criteria to Alappat's invention, the court concluded that the claimed machine was not a "disembodied mathematical concept," but rather a specific machine that produced a "useful, concrete, and tangible result." 52

In the wake of Alappat, the USPTO in 1996 issued new Examination Guidelines for Computer-Related Inventions to assist examiners in determining whether applications reciting such inventions satisfy the criteria for patentability. ${ }^{53}$ Those Guidelines have been amended in light of $E x$ parte Lundgren, a case discussed below, ${ }^{54}$ and are now incorporated in the Manual of Patent Examining and Procedure as part of the Interim Guidelines for Examination of Patent Applications for Patent Subject Matter Eligibility. ${ }^{55}$ Following Alappat, the general criterion set forth in the Guidelines for distinguishing patentable from nonpatentable subject matter is whether the invention carries out a useful, concrete, tangible result. ${ }^{56}$ In a nod to Gottschalk, a factor that remains useful in making this determination is whether use of the claimed invention would preempt all uses of an idea. $^{57}$

48. See id. at 1542 .

49. Id. at 1543 .

50. Id.

51. See id. at 1544.

52. Id.

53. 61 Fed. Reg. 7478 (1996), available at http://www.uspto.gov/web/offices/pac/compexam/examcomp.htm. The USPTO subsequently incorporated the Guidelines into section 2106 of the Manual of Patent Examining and Procedure, and it has periodically amended them, most recently in response to Ex parte Lundgren. 76 U.S.P.Q.2D 1385 (B.P.A.I. 2005). See MANUAL OF PATENT EXAMINING AND PROCEDURE $\S 2106$ (8th rev. ed. Aug. 2006) [hereinafter MPEP].

54. See infra text accompanying notes 79-104.

55. See MPEP, supra note 53, § 2106, at 2100-06.

56. See id. at 2100-06, 2100-09.

57. See id. at 2100-09. Until the August 2006 revision, the Guidelines also suggested, in a nod to Flook and Diehr, that claims reciting only insignificant pre- or postsolution steps might be unpatentable. See MANUAL OF PATENT EXAMINING AND PROCE- 
The culmination of the Federal Circuit's broad interpretation of Diehr has been its decisions in State Street Bank \& Trust Co. v. Signature Financial Group, Inc. ${ }^{58}$ and AT\&T Corp. v. Excel Communications, Inc. ${ }^{59}$ At issue in State Street Bank was an issued patent directed toward a data processing system for implementing an investment structure developed for use in the business of administering mutual funds. ${ }^{60}$ The district court held that the claims were unpatentable as either mathematical algorithms or business methods, but the Federal Circuit reversed. ${ }^{61}$ Construing the Supreme Court trilogy as standing for the proposition "that mathematical algorithms are not patentable subject matter to the extent that they are merely abstract ideas," 62 the court held that "to be patentable an algorithm must be applied in a 'useful' way." ${ }^{.63}$ Notably, the court concluded that "the transformation of data, representing discrete dollar amounts, by a machine through a series of mathematical calculations into a final share price" constituted a "practical application of a mathematical algorithm, formula, or calculation, because it produces a 'useful, concrete, and tangible result'-a final share price momentarily fixed for recording and reporting purposes." ${ }^{64}$ Thus, "[t]he question of whether a claim encompasses statutory subject matter should not focus on which of the four categories a claim is directed to ... but rather on the essential characteristics of the subject matter, in particular, its practical utility." 65

In addition, the court laid to rest what it described as the "illconceived" business methods exception, noting that despite widespread belief ${ }^{66}$ that case law dating back to the nineteenth century had established

DURE $\S 2106$, at $2100-15$ to -16 (8th ed. rev. Aug. 2005) [hereinafter, August 2005 MPEP].

58. 149 F.3d 1368 (Fed. Cir. 1998).

59. 172 F.3d 1352 (Fed. Cir. 1999).

60. State Street Bank, 149 F.3d at 1370.

61. Id. at $1372-73$.

62. Id. at 1373 ("Unpatentable mathematical algorithms are identifiable by showing they are merely abstract ideas constituting disembodied concepts or truths that are not 'useful."').

63. Id.

64. Id.

65. Id. at 1375 .

66. See, e.g., Robert A. Kreiss, Patent Protection for Computer Programs and Mathematical Algorithms: The Constitutional Limitations on Patentable Subject Matter, 29 N.M. L. REV. 31, 85 (1999) (referring to "the repeated comments made by courts, commentators, and the PTO over the years to the effect that business methods are not patentable subject matter"); Leo J. Raskind, The State Street Bank Decision: The Bad Business of Unlimited Patent Protection for Methods of Doing Business, 10 FORDHAM INTELL. PROP. MEDIA \& ENT. L.J. 61, 61-62 \& n.2 (1999) (noting that many of the earlier 
that business methods were unpatentable, neither the Federal Circuit nor its predecessor Court of Customs and Patent Appeals had ever specifically invoked that exception so as to render an invention unpatentable. ${ }^{67}$ Instead, the court characterized each of the cases that appeared to rely on the business methods exception as explainable on some other ground, such as the rule against patenting abstract ideas. ${ }^{68}$ According to the court, at least since the enactment of the 1952 Patent Act, "business methods have been, and should have been, subject to the same legal requirements for patentability as applied to any other process or method." 69 The following year, the court in $A T \& T$ confirmed and extended State Street Bank by upholding the patentability of a process for generating a message record for interexchange telephone calls. ${ }^{70}$ Although the end result of the process was the creation of a "signal useful for billing purposes,"71 the court rejected the argument that Diehr stood for the proposition that process claims containing algorithms are patentable "only if there is a "physical transformation' or conversion of subject matter from one state into another." 72 According to the court, physical transformation "is not an invariable requirement, but merely one example of how a mathematical algorithm may bring about a useful application"; ${ }^{73}$ the only requirement is that the algorithm-containing process "as a whole, produces a tangible, useful, result." 74

Notwithstanding these developments in the law accommodating computer-related art, and their extension to business methods, the USPTO until recently continued to cite Musgrave in its Examination Guidelines for Computer-Related Inventions for the proposition that "[o]nly when the claim is devoid of any limitation to a practical application in the technological arts should it be rejected under 35 U.S.C. 101."75 The Guidelines themselves did not define the term "technological arts," however, giving

decisions rejecting claims to business methods could be explained on other grounds, but nevertheless describing State Street Bank's wholesale rejection of the business methods exception as "startling").

67. State Street Bank \& Trust Co. v. Signature Fin. Group, Inc., 149 F.3d 1368, 1375 (Fed. Cir. 1998).

68. Id. at 1375-76.

69. Id. at 1375 .

70. See AT\&T Corp. v. Excel Commc'ns, Inc., 172 F.3d 1352, 1353 (Fed. Cir. 1999). Judge Plager authored the opinion; there were no dissenting opinions.

71. Id. at 1358 .

72. Id.

73. $I d$.

74. Id. at 1361 .

75. August 2005 MPEP, supra note $57, \S 2106$, at 2100-7. 
examiners wide latitude to interpret patentable subject matter. Several patents that issued in the 1990s and early 2000s--including not only such notorious examples as a method for exercising a cat ${ }^{76}$ and a method for swinging on a swing, ${ }^{77}$ but also to non-computer related business methods $^{78}$ and even the occasional sports move ${ }^{79}$ - appeared to bear little if any relationship to what most people would think of as "technology."

It therefore came as little surprise to many observers when in a recent administrative law decision, Ex parte Lundgren, ${ }^{80}$ the USPTO's Board of Patent Appeals and Interferences put to rest the technological arts exception. ${ }^{81}$ The invention at issue in Lundgren was a method for compensating

76. See U.S. Patent No. 5,443,036 (filed Nov. 2, 1993).

77. See U.S. Patent No. 6,368,227 (filed Nov. 17, 2000).

78. See, e.g., U.S. Patent No. 6,058,941 (filed June 18, 1999) (patenting a method of taping and cutting hair); U.S. Patent No. 5,851,117 (filed Apr. 23, 1997) (patenting a method for training a janitor); U.S. Patent No. 6,014,975 (filed June 6, 1995) (patenting a shaving method); U.S. Patent No. 6,607,389 (filed Dec. 3, 2001) (patenting a method for selecting a jury).

79. See, e.g., U.S. Patent No. 5,993,336 (filed Mar. 31, 1998) (patenting a method of executing a tennis stroke); U.S. Patent No. 5,616,089 (filed Mar. 29, 1996) (patenting a method of putting). To be sure, many of the aforementioned patents and others falling into the same categories have little if any commercial value, and therefore are a social waste only to the extent they clutter up the system. But one cannot assume a priori that all non-technological inventions are so trivial as to never be enforced, or that enforcement would never interfere with other important interests. To my knowledge, for example, no one has yet sought to patent a new baseball pitch, but it may be only a matter of time before someone attempts to do so. See Harold SEYMOUR, Baseball: The EARLy Years (1960) (discussing the debate over which nineteenth century pitcher invented the curveball); Posting of Brett Bull to SI.com, Unwinding the Gyroball, http://sportsillustrated.cnn.com/2007/writers/the_bonus/01/25/matsuzaka.gyroball/ind ex.html (Jan. 30, 2007, 9:07 am) (reporting on a purportedly devastating pitch, the "gyroball," invented in Japan in the 1990s).

80. 76 U.S.P.Q.2D 1385 (B.P.A.I. 2005) (per curiam).

81. In so holding, however, the Board ruled contrary to an earlier non-precedential opinion, Ex parte Bowman, 61 U.S.P.Q.2D 1669, 1671 (B.P.A.I. 2001), which held an invention "which is not tied to any technological art, environment, or machine" to be an unpatentable abstract idea.

Recently, an apparently contradictory but non-precedential opinion of the Board of Patent Appeals and Interferences has come to light. See Ex parte Bilski, Appeal No. 2002-2257 (B.P.A.I. 2006), available at http:www.uspto.gov/web/offices/dcom/bpai/its/fd022257.pdf. Like Lundgren, Bilski involved a business method that was not tied to any particular technology and did not effect a physical transformation. See Bilski, supra, at 2. The Board, in an opinion authored by Judge Barrett (one of the dissenting judges in Lundgren, see infra text accompanying notes 89-96), purported to apply Judge Barrett's analysis and held that the method did not constitute patentable subject matter. See Bilski, supra, at 11, 41-53. The case is currently on appeal to the Federal Circuit. See Patent Law Blog (Patently-O), BPAI 'Informative' Opinion on Business Method Patents, 
a firm manager for reducing the firm's exposure to the risk of antitrust liability; none of the steps of the invention required the use of a computer or other equipment. ${ }^{82}$ The examiner had rejected the application on the ground that the claims read on subject matter "outside the technological arts, namely an economic theory expressed as a mathematical algorithm without the disclosure or suggestion of computer, automated means, apparatus of any kind ...." 83 In a brief per curiam opinion, however, the Board reversed, citing $A T \& T$ for the proposition that "a process claim that applies a mathematical algorithm to "produce a useful, concrete, tangible result without pre-empting other uses of the mathematical principle, on its face comfortably falls within the scope of Section 101."84 The Board rejected the examiner's determination "that there is a separate test for determining whether claims are directed to statutory subject matter, i.e., a 'technological arts' test." ${ }^{95}$ In the board's view, "there is currently no judicially recognized separate 'technological arts' test to determine patent eligible subject matter under Section 101."86

Lundgren nevertheless elicited two strong dissents among the five administrative law judges. In the first dissenting opinion, Judge Smith argued that "the term 'technological arts' should be construed to mean nothing more than a threshold nexus to some field of technology," and that such a requirement is implicit within the "constitutional mandate authorizing Congress to grant patents in order to promote the progress of the useful arts." ${ }^{87}$ In Judge Smith's view, "if the claims recite that the steps were performed by a computer ... the claimed invention would at least have met the constitutional 'technological arts' standard, although [it] would still need to be analyzed under 35 U.S.C. Section 101 for conventional compliance with that section of the statutes." 88 In a much lengthier separate opinion, Judge Barrett expressed agreement with the majority's view

http://www.patentlyo.com/patent/2007/02/bpai_informativ.html (Feb. 16, 2007); see also Patent Prospector, Transformation, http://www.patenthawk.com/blog/2007/02/transformation_1.html (Feb. 19, 2007 , 5:13 $\mathrm{pm}$ ) (quoting Harold C. Wegner asking, " $[\mathrm{I}] \mathrm{n}$ the absence of any intervening judicial precedential to the contrary, on what basis can a new panel simply abrogate the "precedential' Lundgren opinion?").

82. See Lundgren, 76 U.S.P.Q.2D at 1385-86.

83. Id. at 1386 .

84. Id. (quoting AT\&T Corp. v. Excel Commc'ns, Inc., 172 F.3d 1352, 1358 (Fed. Cir. 1999)).

85. Id.

86. Id. at 1388 .

87. Id. (Smith, J., dissenting).

88. Id. 
"that there is no separate and distinct 'technological arts' test." ${ }^{89} \mathrm{He}$ also saw no difficulty with permitting patents to issue on processes the steps of which are completely performed by humans. ${ }^{90}$ Judge Barrett nevertheless dissented from the majority's implication that "the sole test for statutory subject matter is the 'useful, concrete and tangible result' test." ${ }^{\text {" }} \mathrm{He}$ distinguished State Street Bank and AT\&T on the ground that both of these cases "involved transformation of data by a machine, such as a computer," whereas the claim at issue was "broad enough to read on performing the steps without any machine or apparatus. ${ }^{92}$ In Judge Barrett's view, a rule that would conform both to the constitutional mandate to limit patents to the "useful arts" and to the Supreme Court and Federal Circuit case law would define patentable processes as processes that effect "a physical transformation of subject matter (matter or energy) to a different state or thing if it is not tied to a particular machine." ${ }^{93}$ In light of the Federal Circuit cases, however, "the 'subject matter' transformed does not need to be a physical (tangible) object or article or substance, but can be physical, yet intangible, phenomena such as electrical signals or electromagnetic waves." ${ }^{94}$ Under this test, a process would not be patentable if it is abstract, in the sense of not serving a useful purpose, or if it does not transform matter or energy. ${ }^{95}$ Processes that can be implemented by human effort without the use of any device and without transforming matter or energy external to the human actor would, on this view, be unpatentable, even if useful. ${ }^{96}$

Judge Barrett's test therefore would incorporate the old mental steps doctrine, but it would permit computer-related art to be patented as long as the invention carries out a useful purpose, because computer-related art necessarily involves the transformation of matter or energy. Further, this test would permit human implemented processes to be patented as long as

89. Id. at 1389,1390 (Barrett, J., concurring in part and dissenting in part) (concluding that a technological arts test would be unworkable and unfair).

90. See id. at 1428-29.

91. Id.

92. Id. at 1392 .

93. Id. at 1401 .

94. Id. at 1398. Judge Barrett's revision of the traditional "physical transformation" test therefore would recognize many, perhaps most, computer-related inventions as falling within the domain of patentable subject matter. See also Alan L. Durham, "Useful Arts" in the Information Age, 1999 BYU L. REV. 1419, 1464-65, 1513 (arguing that "any 'useful arts' distinction based on physicality is disturbingly superficial," and that many software inventions "have little or no physical effects, yet are equally utilitarian").

95. See Lundgren, 76 U.S.P.Q.2D at 1399 (Barrett, J., concurring in part and dissenting in part).

96. See id. 
they transform matter or energy and are useful. ${ }^{97}$ Process claims that are drafted so as to read on either machine or human implementation would have to satisfy both tests. ${ }^{98}$ Judge Barrett's proposed test did not carry the day, however. In conformity with the majority opinion, the new Interim Guidelines for Examination of Patent Applications for Patent Subject Matter Eligibility neither make reference to a technological arts requirement, nor do they view physical transformation as a sine qua non. ${ }^{99}$ Consistent with the position apparently taken by the Federal Circuit in cases such as Alappat, State Street Bank, and $A T \& T$, the USPTO now purports to apply only the three criteria of useful (meaning that the claim is limited to a practical application), tangible (defined to mean "not abstract"), and concrete (defined to mean "substantially repeatable"). ${ }^{100}$

But perhaps the most anticipated development in the law of patent eligibility in recent years turned out to be something of a non-event. In February 2005, the United States Supreme Court surprised many observers by inviting the Solicitor General to file a brief setting forth the views of the United States on the question of whether the patent claim at issue in Laboratory Corp. of America Holdings v. Metabolite Laboratories, Inc., was invalid by reason of the rule that laws of nature, natural phenomena, and abstract ideas are unpatentable. ${ }^{101}$ Contrary to the Solicitor General's ad-

97. See id. Judge Barrett's dissent may have a good deal to recommend it. See infra text accompanying note 193.

98. See id.

99. See MPEP, supra note $53, \S 2106$, at 2100-11.

100. See id. How far the Federal Circuit is willing to go with respect to patentable subject matter may be tested in the pending case of In re Nuijten. In Nuijten, the USPTO rejected a claim to a "signal with embedded supplemental data, the signal being encoded in accordance with a given encoding process and selected samples of the signal representing the supplemental data, and at least one of the samples preceding the selected samples is different from the sample corresponding to the given encoding process," on the ground that a signal is not an article of manufacture or composition of matter. See John F. Duffy, In re Nuijten: Patentable Subject Matter, Textualism and the Supreme Court, available at http://www.bustpatents.com/sec101/nuij-duf.pdf (last visited Feb. 12, 2007); Harold Wegner, 35 USC $\$ 101$ "Electrical Signal" Patent-Eligibility Test Case, IPFRONTLINE, Aug. 9, 2006, http://www.ipfrontline.com/depts/article.asp?id=12151\&deptid=4. Professor Duffy argues that the claim does recite patentable subject matter because the terms "composition of matter" and "manufacture" mean anything that is neither imaginary nor spiritual. See Duffy, supra. On the other hand, the claim at issue in Nuijten seems more clearly than the claim at issue in Lundgren to fall within the everyday meaning of "technological arts" or, as Professor Duffy puts it, "clever engineering." Id. A reversal in Nuijten therefore might not require calling Lundgren into question. The Federal Circuit heard oral argument in Nuijten in February 2007. See id.

101. Lab. Corp. of Am. Holdings v. Metabolite Labs., Inc., 126 S. Ct. 2921, 2925 (2006) (Breyer, J., dissenting). 
vice, the Court then granted certiorari on the question of whether the patent claim at issue was invalid on the ground that it resulted in "a monopoly over a basic scientific relationship ... such that any doctor necessarily infringes the patent merely by thinking about the relationship after looking at a test result." ${ }^{102}$ The inventors in Metabolite had discovered a naturallyoccurring correlation between the level of homocysteine, an amino acid, in human bodily fluid, and deficiencies of folate and cobalamin. ${ }^{103}$ They then obtained a patent which, in relevant part, claimed a method for diagnosing whether a subject suffers from a folate or colabamin deficiency, comprising (1) testing for the presence of an elevated level of homocysteine; and (2) correlating an elevated level of homocysteine with a folate and cobalamin deficiency. ${ }^{104}$ The assignee of the ensuing patent filed suit against LabCorp for inducing physicians to infringe the patent. The district court entered judgment for the assignee, and the Federal Circuit affirmed. The court, however, failed to address whether the claim, construed to read on a physician's use of any test for homocysteine and subsequent correlation, impermissibly covered a law of nature, i.e., the relationship between elevated homocysteine levels and vitamin deficiencies. ${ }^{105}$

The parties presented oral argument before the Court in early 2006, but the Court thereafter dismissed the writ as improvidently granted. ${ }^{106}$ In dissent, however, Justice Breyer, joined by Justices Stevens and Souter, argued against dismissing the writ, despite the fact that LabCorp had not pressed the law of nature argument at trial and the Federal Circuit had expressed no opinion on the matter. ${ }^{107}$ Justice Breyer then argued that, despite the occasional difficulty of distinguishing between natural phenomena and their applications, the present case was "not at the boundary": the patent claim at issue, in other words, was indistinguishable from the natural phenomenon of the correlation between high levels of homocysteine and folate or cobalamin deficiency. ${ }^{108}$ Justice Breyer also noted that the claim did not involve any "physical transformation of matter," though without deciding whether patentable processes must involve such transformations. ${ }^{109} \mathrm{He}$ also expressed doubt on State Street Bank's implication that processes are patentable as long as they produce a "useful, concrete,

102. See id. at 2925.

103. See id. at 2922.

104. See id. at 2924.

105. See id. at 2924-25.

106. Id. at 2921. As is often the case, the Court offered no reason for its decision to dismiss the writ as improvidently granted.

107. See id. at 2925 (Breyer, J., dissenting).

108. Id. at 2927.

109. See id. 
tangible result," suggesting that this test would have been met in Gottschalk and Flook, as well as in the famous Morse case. ${ }^{110}$

Given the Court's apparent interest in the issues raised in Metabolite, however, it may not be long before the Court grants certiorari in a similar case that more carefully preserves those issues for appellate review. Doing so would allow for some probing of whether the standards developed by the Federal Circuit and the USPTO in the years following Diehr have extended the scope of patentable subject matter too far. For the time being, however, neither the Federal Circuit nor the USPTO appears motivated to step back from the principles that patentable subject matter may pertain to non-technological arts, may read on mental steps, and need not effect any conventional physical transformation. ${ }^{111}$ This trend has extended patentable subject matter beyond the boundaries that most observers would have considered proper a generation ago, as well as beyond the boundaries followed today by other jurisdictions such as the European Patent Office (EPO).

\section{SOME BURKEAN-INSPIRED OBJECTIONS TO THE CONTEMPORARY TREND}

On one level, all of the preceding developments-the elimination of the mental steps and technological arts doctrines, as well as any requirement that there be a physical transformation of matter-seem reasonable. After all, the Patent Act makes no mention of these doctrines, and courts may be correct in inferring that Congress intended the scope of patentable

110. See id. at 2928. In O'Reilly v. Morse, the Supreme Court rejected claim 8 asserted by Samuel F.B. Morse, inventor of the telegraph, directed to "the use of the motive power of the electric or galvanic current, which I call electro-magnetism, however developed, for making or printing intelligible characters, letters, or signs, at any distances." 56 U.S. $62,112-20$ (1854). The case is sometimes read as implicating the principle that laws of nature are unpatentable, though others believe that a better rationale for the result is that the inventor could not enable others to practice unforeseeable embodiments of claim 8 's inventive principle. See Oddi, supra note 28, at 514.

111. Only the Nuijten case so far appears contrary to the trend, but as noted above it turns more on the question of whether signals are compositions of matter or manufactures than on their relation to technology. See supra note 100. Note also that the Supreme Court, or at least some members of the Court, may find reason to express an opinion on the patentability of software-related art in the pending case of Microsoft Corp. $v . A T \& T$ Corp., No. 05-1056 (argued Feb. 21, 2007). Although the case hinges on the Court's interpretation of 35 U.S.C. $\S 271(\mathrm{f})$, during oral argument three justices raised the question of whether software itself is patentable subject matter. See Transcript of Oral Argument, Microsoft Corp. v. AT\&T Corp., No. 05-1056, available at http://www.supremecourtus.gov/oral_arguments/argument_transcripts/05-1065.pdf, at 13 (question of Justice Scalia); id. at 22 (question of Justice Breyer); id. at 26 (question of Justice Stevens). 
subject matter to be broad. ${ }^{112}$ The doctrines themselves may appear arbitrary and subject to capricious interpretation. Who is to say what counts as a physical transformation? In a material universe, every process will cause some sort of physical transformation, if only at the microscopic level or within the human body, including the brain. As noted above, courts never had a clear understanding of the mental steps doctrine, ${ }^{113}$ and reasonable minds may well differ on the subject of what falls within the technological arts. ${ }^{114}$ One may also question whether these now-disfavored doctrines really were part of any firmly-rooted patent law tradition. The mental steps doctrine, as noted above, does not appear in any reported case prior to the twentieth century. ${ }^{115}$ In State Street Bank, the Federal Circuit was able to distinguish earlier cases rejecting patents on business methods on some other ground or grounds. ${ }^{116}$ The Supreme Court may not have intended the dictum in Cochrane v. Deener that processes must involve physical transformations to provide a definitive, limiting definition of what constitutes a patentable process. ${ }^{117}$

Moreover, to the extent that one can read the old doctrines as closing off entire new fields, such as computer-related arts, from the scope of patent protection, they seem arbitrary and short-sighted. Investment in new areas of endeavor may benefit humankind. ${ }^{118}$ On this view, the modern, rational step was to eliminate these archaic doctrines altogether, and to focus on encouraging the invention and disclosure of any and all subject matter so long as it is useful, practical, and sufficiently predictable in its

112. Some observers have argued that the constitutional text authorizing Congress to enact patent laws to "promote the progress of . . the useful arts," U.S. CONST. art. I, $\S 8$, cl. 8, might require that patentable subject matter be limited to the technological arts, as being synonymous with "useful arts." See Ex parte Lundgren, 76 U.S.P.Q.2D 1385 (B.P.A.I. 2005) (Smith, J., dissenting); Malla Pollack, The Multiple Unconstitutionality of Business Method Patents: Common Sense, Congressional Consideration, and Constitutional History, 28 RUTGERS COMP. \& TECH. L.J. 61, 90 (2002). But see Edward Walterscheid, "Within the Limits of the Constitutional Grant": Constitutional Limitations on the Patent Power, 9 J. INTELL. ProP. L. 291, 350, 354 (2002) (arguing that the useful arts are not limited to the technological arts, but rather to any functional subject matter).

113. See supra notes $22-28$ and accompanying text.

114. See Ex part Lundgren, 76 U.S.P.Q.2D 1385, 1389-90 (B.P.A.I. 2005) (per curiam) (Barrett, J., concurring in part and dissenting in part).

115. See supra note 16 and accompanying text.

116. See State St. Bank \& Trust Co. v. Signature Fin. Group, Inc., 149 F.3d 1368, 1375-77 (Fed. Cir. 1998).

117. See 1 ChISUM, supra note $17, \S 1.03[6]$.

118. Accord Durham, supra note 94, at 1514 (arguing, for example, that search engine and virus detection algorithms are "tools for the analysis, manipulation, and transformation of data" and "should be considered at the core of patentable subject matter"). 
effects. Indeed, some advocates of an expansive view of patentable subject matter have argued that even the current rules may not be expansive enough. The amicus brief filed by the Franklin Pierce Law Center in $\mathrm{Me}$ tabolite argued in favor of eliminating the "law of nature" exclusion. ${ }^{119}$ In a related vein, John Schlicher-a practitioner and scholar whose work has greatly influenced my own-has questioned the need for a utility requirement, reasoning that patents on useless inventions would have no value and therefore would impose little social cost. ${ }^{120}$ For all we know, they may be right: the social benefits of these doctrines may be minimal, and the costs of continuing with them may be high, if they discourage, at the margin, some researchers from conducting the sort of basic research that might lead to the discovery of new laws of nature lacking any immediate practical application. On this view, a rational system would permit patentable subject matter to expand into every nook and cranny of human endeavor, and would rely exclusively upon other patent doctrines, such as nonobviousness, to weed out the trivial.

And yet there are reasons to question whether this rational, orderly scenario is entirely correct. Arguments that there is no textual basis within the Patent Act for mental steps or other limiting doctrines only go so far, even if we put aside contrary arguments that there is a constitutional basis for some or all of these limitations. ${ }^{121}$ Much of patent law traditionally has been judge-made: consider, for example, the evolution of the nonobviousness doctrine prior to its codification in $1952 ;{ }^{122}$ the first sale doctrine; ${ }^{123}$ the exclusion of laws of nature and naturally-occurring physical phenomena; ${ }^{124}$ the doctrine of non-statutory double patenting; ${ }^{25}$ or the Federal 11.

119. See Brief for Franklin Pierce Law Center as Amicus Curiae, supra note 14, at 6-

120. See 1 John W. Schlicher, PATENT LaW: Legal ANd ECONOMic Principles $\S 3.3$ (2d ed. 2005); 2 JohN W. Schlicher, PATENT LAW: Legal AND ECONOMIC PrinCIPLES $\S 13.22$ (2d ed. 2005).

121. See supra note 112 .

122. See Graham v. John Deere \& Co., 383 U.S. 1, 5-16 (1966) (discussing the evolution of the "inventiveness" doctrine prior to the codification of the nonobviousness doctrine in 1952, though also suggesting that inventiveness or nonobviousness may be a constitutional requirement).

123. The first-sale doctrine entitles the owner of a lawfully-made article embodying the patented invention to use and resell the article, without permission of the patent owner, unless the patent owner has validly conditioned the sale of that article in some relevant respect. See, e.g., Mallinckrodt, Inc. v. Medipart, Inc., 976 F.2d 700, 706-08 (Fed. Cir. 1992). It has never been explicitly codified in the Patent Act.

124. See Diamond v. Diehr, 450 U.S. 175, 185 (1981); Diamond v. Chakrabarty, 447 U.S. 303, 308 (1980). 
Circuit's "useful, concrete, and tangible" test, the latter two portions of which have neither a textual basis nor are interpreted to mean what those terms mean in ordinary discourse. ${ }^{126}$ And while doctrines such as technological arts or mental steps may lack a long pedigree as measured by explicit statements in the case law, the absence of such statements may simply reflect a widespread, unchallenged understanding that patentable subject matter did not extend so far. ${ }^{127}$

125. Under the doctrine of non-statutory double patenting, one may not patent an obvious variation of one's own patented invention, absent the filing of a terminal disclaimer under which the second patent covering the obvious variation expires on the same date as the first patent. See Geneva Pharms., Inc. v. Glaxosmithkline PLC, 349 F.3d 1373, 1377-78 (Fed. Cir. 2003).

126. See supra text accompanying note 100 .

127. See, e.g., 1 William C. Robinson, The LaW of Patents for USEFul INVEnTIONS $\S 66$, at 101 n.2 (1890) (citing with approval Morton v. N.Y. Eye Infirmary, $17 \mathrm{~F}$. Cas. 879 (C.C.S.D.N.Y. 1862) (holding invalid a patent on "a method of rendering patients insensible to pain during surgical operations," despite the fact that the invention "conferred inestimable benefits upon the whole race of man")); Robert I. Coulter, The Field of the Statutory Useful Arts, Part II, 34 J. PAT. OFF. SOC'Y 487, 494, 505 (1952) (arguing that, in historic context, the "useful arts" are distinct from the liberal and fine arts, and also that "mental operations per se ... are not patentable," although "practical technological methods which provide modes or means linking elemental agencies (including the human mind) to produce the useful result" are); Pamela Samuelson, Benson Revisited: The Case Against Patent Protection for Algorithms and Computer Software, 39 EMORY L.J. 1025, 1036 n.34 (1990) (noting little explanation, in judicial opinions, for the mental steps doctrine, but proposing that "this lack of explanation instead may be a sign of how far outside the bounds of the patent system mental processes are perceived to be"); John R. Thomas, The Patenting of the Liberal Professions, 40 B.C. L. REV. 1139 , $1142,1145-47,1164$ (1999) (referring to "our long-held sense of the reach of the patent system" as "somehow cabin[ing] the scope of patentable subject matter," and citing nineteenth and twentieth century case law articulating a physical instantiation requirement). To be sure, even if such an understanding existed relatively early on, it would not necessarily bind modern-day courts; arguments for tradition always beg the question concerning the level of generality at which the tradition should be considered binding. See Sunstein, supra note 5, at 381. Many observers today might disagree, for example, with the specific holding of Morton v. N.Y. Eye Infirmary, 17 F. Cas. 879 (C.C.S.D.N.Y. 1862) (though even today medical methods, though patentable, are not generally enforceable, see 35 U.S.C. $\$ 287(\mathrm{c})$ ), to say nothing of other patent-limiting cases (including Parker $v$. Flook, 437 U.S. 584 (1978)) that rest upon what John Duffy and Robert Merges refer to as the "nature's library" fallacy, i.e., that applications of a newly discovered law of nature may be obvious if the law of nature itself is considered part of the prior art. See ROBERT P. Merges \& John F. Duffy, PATENT LAW AND POlicy: Cases and Materials 108 (3d ed. 2002). But as I argue above, courts also should consider the possibility that the assumptions underlying some of the now-disfavored doctrines embodied a degree of underappreciated wisdom that we should not be too quick to jettison entirely. 
To the extent there was some such common understanding, by the mid-twentieth century and quite possibly much earlier, regarding the limited scope of patentable subject matter, a Burkean perspective might suggest that we should not be too quick to discard that understanding altogether absent some compelling need. As I suggested in the Introduction, I am speaking here not of Burke's specific views on the political and social issues of his day, but rather of the Burkean attitude of prudence: the idea that traditional practices may embody the unarticulated and underappreciated wisdom of many people and many times, and that changes from tradition should be undertaken, when necessary, with due regard to that wisdom. Taking a page from Oakeshott, ${ }^{128} \mathrm{I}$ also do not contend that any specific results necessarily flow from traditional conservativism; practical wisdom cannot be reduced to mere technique. What I will suggest, more in the nature of a conversation or discussion, are some ways in which a Burkean-inspired appreciation for the latent wisdom of tradition and custom might be useful in approaching some of the recent controversies over patentable subject matter. To the extent that old limitations embodied a degree of wisdom-and to the extent no one has yet articulated a compelling policy reason, such as a perceived underinvestment in the production of non-technological processes, in favor of the wholesale jettisoning of these traditional rules-courts might be well-advised to reconsider some of these rules. ${ }^{129}$ At the same time, nothing in this Burkean-inspired approach suggests that the law of patents ought to be frozen at the time of some mythical golden age. Patent law must keep pace with the times, and it probably would be inadvisable-as well as a likely violation of the

128. See supra note 3.

129. Put another way, no one is sufficiently well-informed to know how to craft the patent eligibility requirement so as to maximize the surplus of social benefits over social costs. Although it is conceivable that defining the scope of patentable subject matter very broadly-even doing away with the requirement altogether-might induce more invention, discovery, and disclosure, it also may induce more transaction, monopoly, and rentseeking costs. The marginal payoff may well be negative, in light of other incentives to discovery (such as fame, prizes, and direct or other indirect subsidies) and the potentially exponential increase in transaction costs in particular. Unfortunately, this observation does not tell us precisely how to differentiate patentable from unpatentable subject matter; indeed, the question may defy empirical analysis. One must rely in large part upon non-verifiable assumptions concerning the likely consequences, including unintended consequences, of legal rules. The Burkean perspective suggests that tradition provides a set of such assumptions, departures from which should be based upon evidence that modifications are necessary to adapt the law to changing times, rather than upon some perceived need to conform patent law to some model of Cartesian rationality. 
TRIPs Agreement ${ }^{130}$ - to exclude computer and business-related art from the scope of patent eligibility altogether. Reintroducing some of the traditional limitations on patent eligibility, though subject, as we shall see, to appropriate reforms, might restore some needed balance to the system. In particular, one may view the physical transformation, mental steps, and technological arts requirements as embodying principles which still merit respect, even if not absolute fidelity. Among these principles are the following.

Laws of nature and basic research should remain unpatentable, and efforts should be made to ensure that clever patent drafting does not eviscerate this principle. As suggested above, even this time-honored principle is not completely unassailable from a utilitarian standpoint. Allowing patents to issue on laws of nature or other tools of basic research-which currently fall outside the scope of patentability, both as a matter of patentable subject matter doctrine and under the current understanding of the utility doctrine ${ }^{131}$ - might conceivably encourage some additional investment in their discovery. Nevertheless, the principle that laws of nature and basic research should remain outside the patent system is also clearly rational, in light of both the potential for a contrary rule to generate enormous social costs and the availability of other time-honored means, such as direct government subsidies, for inducing basic discoveries. Indeed, a rule forbidding the patenting of laws of nature and basic research rests comfortably within a web of traditional limitations on patentability, including not only utility but also the inherency doctrine, ${ }^{132}$ which rests in part upon similar assumptions concerning the value of a more limited role of the patent system in facilitating basic research. Patents on laws of na-

130. See TRIPs Agreement, supra note 9, art. 27 (subject to certain permissible exceptions, "patents shall be available for any inventions, whether products or processes, in all fields of technology, provided that they are new, involve an inventive step, and are capable of industrial application"). Note, however, that the TRIPs Agreement does appear to permit restricting patents to "fields of technology."

131. See In re Fisher, 421 F.3d 1365, 1371 (Fed. Cir. 2005). Indeed, the best response to Schlicher's argument against the utility doctrine is precisely this: by requiring basic research tools and other fundamental building blocks to remain in the public domain, the utility doctrine performs a function more important than merely discouraging investment in useless, and presumably valueless, invention.

132. The inherency doctrine forbids the patenting of discoveries which are inherently present in the prior art, regardless of whether the benefits of the discovery have been previously appreciated, as long as the public has been deriving the benefits of the discovery all along. Although the case law has long been marked by confusion, the more recent Federal Circuit decisions have reconciled the competing strands along these lines. See, e.g., Toro Co. v. Deere \& Co., 355 F.3d 1313, 1320-21 (Fed. Cir. 2004); Dan L. Burk \& Mark A. Lemley, Inherency, 47 WM. \& MARY L. REV. 371 (2005). 
ture would also lead to administrative difficulties and would intrude upon personal autonomy in troubling ways. Had Sir Isaac Newton been able to patent the law of gravity, for example, how exactly would he have been capable of excluding others from using it, and should society have let him try? Perhaps patent eligibility standards can be one tool for ensuring against clever "drafting around" that claims as one's invention all or most practical applications of such a physical law.

When possible, the patent system should strive to avoid conflicts with free speech, copyright, privacy, and other important competing interests. As other scholars have noted, an overly expansive eligibility standard may result in the granting of patents that threaten to invade free speech, privacy, or other constitutionally-protected rights. Dan Burk, for example, has noted that, to the extent that software embodies expression that is entitled to a degree of First Amendment protection, patents that read on competing software products - that is, that render competing products infringing and thus potentially subject to an injunction--raise potentially disturbing constitutional issues. ${ }^{133}$ These issues may be more problematic in the context of patent than copyright law, insofar as copyright only protects original expression (or selection or arrangement), and not its functional equivalents. ${ }^{134}$ The famous idea/expression dichotomy ${ }^{135}$ helps to ensure that copyright rights do not intrude too far upon the First Amendment guarantee of freedom of speech. ${ }^{136}$ A patent claim that is drafted broadly enough, by contrast, will read on a functionally-equivalent invention, ei-

133. See Dan L. Burk, Patenting Speech, 79 TEX. L. REV. 99, 150 (2000).

134. See 17 U.S.C. $\S 102(a)$, (b) (2000).

135. The basic principle is that copyright subsists in an author's original expression of ideas or fact, or in her original selection or arrangement of those ideas or facts, but not in the ideas or facts themselves. See Thomas F. Cotter, Memes and Copyright, 80 TUL. L. REV. 331, 354 (2006) (citing sources).

136. See Eldred v. Ashcroft, 537 U.S. 186, 219 (2003); Harper \& Row Publishers, Inc. v. Nation Enters., 471 U.S. 539, 560 (1985). This is not to say that copyright doctrine necessarily makes sufficient accommodations to freedom of speech; the point is arguable, to say the least. See, e.g., Neil Weinstock Netanel, Locating Copyright Within the First Amendment Skein, 54 STAN. L. REV. 1, 13 (2001); Jed Rubenfeld, The Freedom of Imagination: Copyright's Constitutionality, 112 YALE L.J. 1, 5 (2002). Determining precisely where expression leaves off and idea begins is not easy, because copyright covers not only exact copying but also substantially similar copying. See, e.g., Arnstein v. Porter, 154 F.2d 464, 468 ( 2 d Cir. 1946). But copyright at least makes an effort to reconcile property rights with free speech rights. Because patent rights are generally broader in scope than copyrights, however, and because patent law lacks anything resembling a fair use defense, there is no obvious way to address the potential conflict of patent law and the First Amendment in cases in which that conflict arises. 
ther literally or under the doctrine of equivalents. ${ }^{137}$ When patents covered only traditional forms of technology, the broader scope of patent rights rarely presented a conflict with other bodies of law; now that patents and copyrights sometimes both read on the same subject matter, however, the potential for patent law to negate the public's right to incorporate noncopyrightable ideas into competing software products can present formidable difficulties in accommodating the competing interests. ${ }^{138}$ Burk therefore suggests that " $t]$ he introduction of expressive subject matter into patent law may require revival or reformation" of either the mental steps or printed matter doctrine, "in order to re-establish the line between function and expression in patentable subject matter." 139 In a related vein, Kevin Collins argues that strict liability for patents that would render infringing the (possibly involuntary) act of thinking raises constitutional problems, although for Collins the principal problem is that such patents effectively remove subject matter from the public domain. That is, if the point of novelty subsists only in the mental step, as in the claim at issue in Metabolite, a patent effectively renders it impossible to use subject matter (e.g., a naturally-existing correlation between two phenomena) that itself is nonpatentable subject matter. ${ }^{140}$

But John Thomas has pointed to what is perhaps the most serious problem posed by the expansion of patentable subject matter, namely its potential impact upon personal liberties. ${ }^{141}$ As Thomas notes, patents in recent years have claimed among other things methods for terminating

137. The defendant's product or process infringes under the doctrine of equivalents if that product or process contains each element found in the patented invention, or the substantial equivalent thereof; an element is the substantial equivalent of another if a person of ordinary skill in the art would know that the substituting element is interchangeable with the substituted element. See Warner-Jenkinson Co. v. Hilton Davis Chem. Co., 520 U.S. 17, 37 (1997).

138. At least in some contexts, the U.S. Supreme Court has been reluctant to interpret federal intellectual property laws in such a way as to negate rights that it views as being conferred upon the public under other federal intellectual property laws. See, e.g., Dastar Corp. v. Twentieth Century Fox Film Corp., 539 U.S. 23, 34-35 (2003); TrafFix Devices, Inc. v. Mktg. Displays, Inc., 532 U.S. 23, 32 (2001). Enforcement of the printed matter doctrine remains one way of trying to keep patent and copyright separate. See supra note 15 (discussing the printed matter doctrine). However, ascertaining the boundaries of that doctrine can be quite difficult. See Burk, supra note 133, at 141-45.

139. Burk, supra note 133 , at 161.

140. See Kevin Emerson Collins, The Problem of Insufficient Thought Control: Reflexive Thought and Constructive Nonvolition in Patent Law 54-56 (unpublished manuscript, on file with author).

141. See John R. Thomas, Liberty and Property in Patent Law, 39 Hous. L. REV. 569,570 (2002). 
pregnancy, for advising clients with respect to tax and regulatory compliance, and for various methods of communication (including, but not limited to, methods of advertising). ${ }^{142}$ In many instances, constitutional principles would almost certainly preclude the government from directly prohibiting the practices that comprise the subject matter of these patents, and yet the owner of an enforceable patent on a method for inducing abortion, providing tax advice, or advertising a product could obtain an injunction forbidding others from the unauthorized practice of the very same conduct. ${ }^{143}$ Whether constitutional law itself should play a role in constraining the courts from enforcing patents that implicate personal liberty interests presents difficult questions concerning the interpretation of the state action doctrine, among other things. ${ }^{144}$ Thomas himself argues that "the fashioning of a subconstitutional restraint seems the best way" to accommodate the competing interests, ${ }^{145}$ and in other work has argued in favor of retaining the technological arts and physical transformation doctrines as a way to stem the tide of liberty-intrusive patents. ${ }^{146}$ To some extent, these traditional limitations on patentable subject matter may have implicitly recognized the value in protecting liberty interests from being undermined by the patent system. ${ }^{147}$ The liberty-intrusive patents Thomas decries have little to do with technological arts or physical transformations, at least not within the conventional meaning of those terms.

The virtue of redundancy. Many of the legal standards that have grown up around patent eligibility make use of concepts that one can already find in other patent doctrines, most notably utility and inherency. As noted above, like patent eligibility one can understand the utility requirement as a tool for ensuring that basic research remains in the public domain. ${ }^{148}$ So too can inherency, which properly understood prevents inventors from

142. See id. at $580-90$.

143. See id. at 592 (characterizing as a "disturbing question" the issue of whether patents may "restrict personal liberties in ways that legislation cannot").

144. See id. at 592-619.

145. Id. at 609.

146. See Thomas, supra note 127 , at 1143,1175 .

147. To be sure, modern-day Burkeans may disapprove of constitutional doctrine that recognizes, among other things, a penumbral constitutional right to privacy and free speech rights that permit flag-burning and the distribution of pornographic materials - or they may not, to the extent that these rights, whether legitimate or not in their inception, have become long-settled artifacts of the constitutional landscape. See Sunstein, supra note 5, at 368-69, 392-94. My point is merely that, to the extent our legal traditions embrace a degree of respect for personal autonomy, freedom of speech, and other liberty interests, however one interprets them, the potential for patent law of all things to interfere with these interests ought to be a matter of concern.

148. See supra note 132 and accompanying text. 
claiming inventions the benefits of which the public has been enjoying, albeit unwittingly, prior to the inventor's discovery of the natural principle at issue. ${ }^{149}$ Although this observation might lead one to conclude that a rational patent system could rely exclusively upon these other doctrines to weed out inventions which, for policy reasons, should remain unpatentable, the existence of other doctrines that embody common assumptions on the limited role of the patent system may provide greater confidence in the value of restraint. Moreover, redundancy provides some assurance that, even if one doctrine is misapplied in a given instance, another will serve as a backup to attain the correct outcome. ${ }^{150}$

All of this reasoning leads me to conclude that, despite some potential drawbacks, the technological arts, mental steps, and physical transformation doctrines may have possessed some underappreciated virtues. Abandoning them entirely, in the interest of attaining a more rational, logical patent system, may well have been precipitate. And yet to state that these doctrines may have possessed some latent merit does not necessitate that they be revived in their original state. Times do change, after all, and legal doctrines must change with them. In particular, an expansive reading of the mental steps and physical transformation doctrines would render a broad swath of computer-related art unpatentable, to the extent that the art makes use of mathematical algorithms which, in theory, one could perform mentally, or transforms one set of data into another set of data. Although some opponents of software patents might not mind seeing such changes, in my view a radical return to the status quo ante would be just as imprudent as staying the present course. Software-related inventions, after all, can and do add substantial value to the economy. Moreover, such a return might be difficult to reconcile with the TRIPs Agreement, which for better or worse requires all member nations to make patents "available for all inventions, whether products or processes, in all fields of technology, provided that they are new, involve an inventive step and are capable of industrial application." "151 Reversing State Street Bank's rule in favor of business method patents might involve similar problems, at least to the extent some such methods relate to a "field[ ] of technology," and would

149. See supra note 133 and accompanying text.

150. At the same time, policymakers must recognize that satisfaction of the patent eligibility standard is only one of many requirements for patent protection. Many of the common complaints concerning the patenting of computer-related art, for example, may be better directed at problems involving nonobviousness and disclosure, rather than subject matter. See supra note 122 (discussing nonobviousness); Julie E. Cohen \& Mark A. Lemley, Patent Scope and the Software Industry, 89 CALIF. L. REV. 1, 13-14 (2001) (discussing disclosure).

151. TRIPs Agreement, supra note 9, art. 27.1. 
require legislative action insofar as Congress, in the wake of State Street Bank, to enact a new provision to the Patent Act that makes specific reference to business method patents. ${ }^{152}$ A more fruitful avenue for further analysis therefore would be to investigate more carefully the circumstances under which these doctrines might play a useful, albeit altered, role in the modern patent system.

\section{SOME MODEST STEPS TOWARD REFORM}

I have chosen to focus my attention on three specific doctrines, namely technological arts, mental steps, and physical transformation, as candidates for a possible revival. Yet I have not said much to this point about precisely how I envision these doctrines could be grafted back into existing law. None of these doctrines were clearly defined in the past, and in any event a mindless return to past practice would probably, as I suggested above, be unwarranted. At the same time, however, to try to define their future contours definitively now would be arrogant; the wisdom of the many is greater than that of any individual participant, including me. I will, however, set forth some tentative observations on the ways in which the law might incorporate some of the wisdom of the past, in the hope that this exercise will stimulate others to build on this work and the work of other scholars who have recently contributed to this ongoing discourse. I first discuss technological arts and mental steps; I then, briefly, discuss physical transformation.

\section{A. Technological Arts and Mental Steps}

An initial difficulty in implementing a technological arts requirement lies in defining the term "technological arts," but those difficulties may be exaggerated. Although there may never be a definition of technology that everyone can agree upon completely, there are some serious candidates for an adequate definition that would likely resolve the vast majority of cases. Professor Thomas, for example, having canvassed the works of historians and philosophers of technology as well as the case law of several other countries, proposes as a working definition "the production or transformation of artifacts through the systematic manipulation of physical

152. See 35 U.S.C. $\$ 273(b)(1)$ (1999) (exempting from liability a person who would otherwise infringe a method patent, "if such person had, acting in good faith, actually reduced the subject matter to practice at least one year before the effective filing date of such patent, and commercially used the subject matter before the effective filing date of such patent"); $i d$. $\$ 273(\mathrm{a})(3)$ (defining the relevant method covered by this provision to be "a method of doing or conducting business"). 
forces." ${ }^{153}$ Alternatively, one version of an (ultimately defeated) European Council Directive on computer-related patents would have defined technology as "the use of controllable forces of nature to achieve predictable results." 154 And Professor Durham, arguing that software engineering should be viewed as a branch of technology, would nevertheless limit patentability to inventions which "reflect the programmer's art rather than the non-technological art in whose service the programmer's art is employed." 155 Thus, while there will undoubtedly be some cases at the margin, and not everyone will agree precisely where the boundary lies, it is hard to believe that if more attention were focused on the matter, a workable definition would lie forever beyond our reach. The need to apply some sort of "technological arts" criterion has hardly led other countries' and regions' patent systems to grind to a halt; it is hard to see why it should be an insurmountable obstacle for ours. ${ }^{156}$

Assuming that we can agree upon a definition, a second problem, relating also to mental steps, is to determine whether the USPTO should apply that definition to the invention as a whole or whether the USPTO should apply some variation on the point of novelty approach instead. In

153. See Thomas, supra note 127 , at $1142,1178-80$ (drawing upon definitions of "capable of industrial application" in other nations' laws).

154. See European Parliament legislative resolution on the proposal for a directive of the European Parliament and of the Council on the patentability of computerimplemented inventions (COM(2002) 92-C5-082/2002-2002/0047(COD)), art. 2(c) (Sept. 24, 2003), available at http://www.europarl.europa.eu/sides/getDoc.do?pubRef=//EP//TEXT+TA+P5-TA-2003-0402+0+DOC+XML+V0//EN. As noted above, the $\mathrm{EPO}-$ not to be confused with the European Council or the European Union-requires patentable inventions to demonstrate a "technical effect," but as far as I can tell the term is not defined in the European Patent Convention or regulations. See Case No. T 0931/95 - 3.5.1, at 16 (noting that "the meaning of the term 'technical' or 'technical character' is not particularly clear," but that this is also true of the term "invention"; that "the fact that the exact meaning of a term may be disputed does in itself not necessarily constitute a good reason for not using that term as a criterion"; and finally that "case law may clarify the issue").

155. Durham, supra note 94, at 1521-22 (emphasis added).

156. There is clearly some force, however, to the argument that the doctrines discussed in the text above can lead to unnecessary formalistic distinctions; for example, a technological arts requirement might distinguish between (potentially patentable) systems and (potentially unpatentable) methods, even if the underlying inventive principle is identical. See John A. Squires \& Thomas S. Biemer, Patent Law 101: Does A Grudging Lundgren Panel Decision Mean that the USPTO Is Finally Getting the Statutory Subject Matter Question Right?, 46 IDEA 561, 567 (2006). Be that as it may, if a technological arts requirement in general serves a beneficent purpose, some formalism may be an unintended but manageable byproduct thereof. It is hardly obvious that a rule favoring systems over methods will have any significant impact on patent incentives, particularly if method claims can often be drafted as system claims, and vice versa. 
the present context, an "invention as a whole" approach would screen out claims, such as the method claims at issue in Lundgren, that have no technological purpose and that can be performed by non-technological means. If merely automating any process necessarily removes any technological arts or mental steps impediment, however, the reform would not screen out much else. It might be easy to evade such a rule without sacrificing much claim breadth by simply drafting the claims so that the invention must be performed technologically, for example by computer means. ${ }^{157}$ The invention as a whole approach also would do little, if anything, to revive the mental steps doctrine; surely most process claims can be drafted to include at least one step that need not, or must not, be performed mentally. For that matter, claims not so drafted might run afoul of whatever remains of the mental steps doctrine today after Musgrave, without any further reform.

All of this reasoning leads me to suggest that if technological arts and mental steps are to perform a modest but non-negligible function in preventing patents from intruding upon liberty and other important interests, it might be more fruitful to reconsider application of a point of novelty approach. To be sure, and as discussed in Part II, the Court of Customs and Patent Appeals disapproved of the point of novelty approach in Musgrave, ${ }^{158}$ while the U.S. Supreme Court appears to have dispensed with it in Diehr. ${ }^{159}$ The arguments against the point of novelty approach appear in many ways compelling. For one thing, the point of novelty approach appears to depart from standard concepts of novelty and nonobviousness, which depend upon an evaluation of the subject matter as a whole in relation to the prior art, and not upon individual claim elements. ${ }^{160}$ Courts can,

157. Depending on how one defines technology, even pencil and paper might provide sufficient technological means. See Case T 0258/03 - 3.5.1, Hitachi (EPO Bd. App., Apr. $21,2004)$, 14.6 , available at http://legal.european-patent-office.org/dg3/pdf/t03$0258 \mathrm{ep} 1 . p d f$. Requiring the invention as a whole to have a technological purpose, rather than merely technological means, would avoid this problem but might still cover a vast territory.

158. See In re Musgrave, 431 F.2d 882,891 (C.C.P.A. 1970).

159. See Diamond v. Diehr, 450 U.S. 175, 204-05 (1981). Note, however, that Professor Collins defends his point of novelty approach, discussed infra notes 187-192 and accompanying text, against the charge that it cuts against the grain of considering the patent claim as a whole, on the grounds, inter alia, that Diehr's apparent disapproval of the point of novelty approach can be interpreted narrowly. See Collins, supra note 27, at 55 .

160. A claimed invention lacks novelty if, inter alia, another invention contains all of the "elements" or "limitations" of the claimed invention, arranged in the same order. 35 U.S.C. $\S 103$ (stating it is obvious if "the difference between the subject matter sought to be patented and the prior art are such that the subject matter as a whole would have been 
and frequently do, find a combination of elements, each one of which is found in the prior art, to be both novel and nonobvious when considered as a whole. ${ }^{161}$ And as the court suggested in Musgrave, the point of novelty approach seems illogical in the sense that it contemplates that the very same invention may fall within the scope of patentable subject matter at one point in time, when the prior art is more limited in scope and thus does not anticipate the non-mental or non-technological steps, but not at another point when the prior art embraces those steps. ${ }^{162}$

And yet as Holmes said and Burke might have said, "[t]he life of the law has not been logic; it has been experience." ${ }^{163}$ Experience suggests that a point of novelty test is not unworkable. For one thing, the USPTO

obvious at the time the invention was made to a person having ordinary skill in the art"); see Connell v. Sears, Roebuck \& Co., 722 F.2d 1542, 1548 (Fed. Cir. 1983).

161. See, e.g., Panduit Corp. v. Dennison Mfg. Co., 774 F.2d 1082, 1095 (Fed. Cir. 1985).

162. See In re Musgrave, 431 F.2d 882,889 (C.C.P.A. 1970). Consider too the claim at issue in Metabolite. If (Case 1) that claim comprised only the single limitation of testing for the presence of an elevated level of homocysteine, it would constitute patentable subject matter (but would be unpatentable for lack of novelty). If instead (Case 2) the claim comprised the two steps of testing and correlating (as the actual claim at issue in Metabolite did), then under a point of novelty test that would render the subject matter unpatentable unless the point of novelty resides in steps other than the mental step. The addition of the extra element would render the subject matter unpatentable. Addition of a third step (Case 3) - for example, instructing the patient regarding the diagnosis of cobalamin deficiency, or administering treatment for the deficiency-might bring the claim back into patentable subject matter territory. This series of results-moving from patentable subject matter in Case 1 to unpatentable subject matter in Case 2, then back to patentable subject matter in Case 3-seems bizarre if one views patentable subject matter as an ontological state. If on the other hand patentable subject matter is perceived as simply a legal conclusion, a label reflecting certain underlying policy determinations, the conclusion is less odd. The relevant policies may counsel against patentability only in Case 2 (though again, other policies, those reflected in the novelty doctrine, surely would counsel against patentability in Case 1). But I concede that the result is inelegant and untidy.

163. Oliver Wendell Holmes, JR., The Common Law 1 (Dover Publications 1991) (1881). Holmes was not a respecter of tradition in the sense that Burke was. See Oliver Wendell Holmes, The Path of the Law, 10 HARV. L. REV. 457, 469 (1897) ("It is revolting to have no better reason for a rule of law than so it was laid down in the time of Henry IV."); Sunstein, supra note 5, at 398 (comparing and contrasting Holmes and Burke); cf. BURKE, supra note 3, at 81 (describing jurisprudence as "the pride of human intellect, which, with all its defects, redundancies, and errors, is the collected reason of ages, combining the principles of original justice with the infinite variety of human concerns"). Neither Burke nor Holmes, however, as I understand them, had much patience with efforts to conform law or other institutions to some grand, a priori theory. 
has continued to apply point of novelty in two limited contexts. ${ }^{164}$ And the European Patent Office (EPO) continues to apply a variation on the point of novelty test to the present day to determine the patentability of computer-related art. At issue in a recent EPO case on point, Hitachi, ${ }^{165}$ was an automatic auction method carried out by means of a computer. The examiner had concluded that the method was a "business method as such," rather than an "invention," and thus fell outside the scope of patentable subject matter under article 52(1) of the European Patent Convention. ${ }^{166}$ Under a version of the point of novelty test, known as the "contribution approach," that the EPO had articulated in some earlier cases, this conclusion appeared correct. That approach advised the examiner to isolate the "'new features' of an invention and features of that invention which are known from the prior art," 167 and then determine whether the new features, as opposed to the invention as a whole, exhibited a "technical char-

164. First, as noted above, the printed matter doctrine renders an invention unpatentable if the only distinction between the invention and the prior art is nonfunctional descriptive material. See In re Ngai, 367 F.3d 1336, 1339 (Fed. Cir. 2004). Second, U.S. courts continue to apply a point of novelty approach with respect to design patents. See Lawman Armor Corp. v. Winner Int'1, L.L.C., 437 F.3d 1383, 1384-85 (Fed. Cir. 2006), as clarified, 449 F.3d 1190, 1192 (Fed. Cir. 2006). Moreover, if the words "point of novelty" set off too many alarms among the patent bar, maybe it would help to call it something else. In conversation, Richard Stern has suggested the use of the alternative term "departure from the prior art."

165. Case T 0258/03 - 3.5.1, Hitachi (EPO Bd. App., Apr. 21, 2004), available at http://legal.european-patent-office.org/dg3/pdf/t030258ep1.pdf; see also Case T 0931/95 - 3.5.1, Pension Benefit Systems Partnership (EPO Bd. App. Sept. 8, 2000), ๆ 6, available at http://legal.european-patent-office.org/dg3/pdf/t95093 leu1.pdf (rejecting also the "contribution" approach, though not as definitively as in Hitachi). For a recent British case declining to follow Hitachi, and instead applying a test that would exclude more software and business-related inventions from the scope of patentable subject matter, see Lord Justice Jacob's opinion in and appendix to Aerotel Ltd. v. Telco Holdings Ltd (U.K. Ct. App. Oct. 27, 2006), available at http://www.bailii.org/ew/cases/EWCA/Civ/2006/1371.html. Lord Justice Jacobs also appears to read another recent EPO Board of Appeals decision, Case T 0424/03 - 3.5.1, Microsoft Corp., (EPO Bd. App. Feb. 23, 2006), as not requiring an inventive step that is technical in character. See Aerotel, supra, at 97 26, 113-14. I am not convinced that this is the result the Board intended in Microsoft, though the Board's discussion of inventive step and technical character perhaps could be clearer. See Microsoft, supra, ๆף 5.2, 7. If Lord Justice Jacobs's interpretation is correct, however, and if the EPO were to follow that interpretation in future cases, the EPO standard arguably would differ from the current U.S. approach only in requiring some relation to technological arts-and only a minimal relation at that. See infra note 174 and accompanying text.

166. See Case T 0258/03, Summary of Facts and Submissions II III.

167. Id. ๆ3.3. 
acter." 168 In other words, the question was whether "the invention involves some contribution to the art in a field not excluded from patentability." 169 In Hitachi, however, the Board of Appeals reversed this earlier case law, holding "any comparison with the prior art ... to be inappropriate for examining the presence of an invention"; 170 "a mix of technical and non-technical features may be patentable." "171 As far as subject matter is concerned, all that matters "is the presence of technical character which may be implied by the physical features of an entity or the nature of an activity, or may be conferred to a non-technical activity by the use of technical means." ${ }^{172}$ The only "activities falling within the notion of a non-invention 'as such' would typically represent purely abstract concepts devoid of any technical implications."

One might conclude that the Board was overthrowing point of novelty in its entirety, opting for the USPTO's approach of finding patentable subject matter as long as the inventor does not claim a computer program per se. That conclusion would be premature, as the Board then went on to conclude that the auction method at issue was unpatentable because it did not "represent a nonobvious technical solution to a technical problem."174 In other words, in assessing the "inventive step" requirement-the analogue to the U.S. Patent Act's nonobviousness requirement-the examiner should take "account of only those features which contribute to a technical character." 175 Applying that standard to the auction method, the Board noted first that the "overall aim of the claimed method" was to identify a successful bidder, and therefore that the aim lacked a technical character. ${ }^{176}$ The dispositive question would therefore be whether the inventive steps themselves were technical in nature. The Board concluded, however, that the technical steps of the invention, such as those involving data transmission and storage, were not inventive, but rather standard in the field. ${ }^{177}$ The inventive steps, by contrast, involving "using the stored information to arrive at the successful bidder," concerned only prices and thus lacked any technical character. The prominent inventive feature "is

168. See id. ๆๆ $3.1,3.2$.

169. $I d$. $\ 3.2$.

170. Id. $\ 3.3$.

171. Id. $₫ 3.4$.

172. Id. $\uparrow 4.5$.

173. Id.; see also id. $\mid 4.6$ (suggesting that even the "act of writing using pen and paper" involves technical character).

174. Id. ๆ 4.6.

175. Id. ๆ 5.3 .

176. Id. ๆ 5.4 .

177. See id. 
fundamentally independent of the computer arrangement for performing the auction" and "could just as well be used for conducting a Dutch auction without computer support." 178 In short:

The invention can therefore be regarded as a mere automation of the non-technical activity of performing a Dutch auction in the absence of bidders. Any ingeniousness required to develop the rules for the hypothetical auction cannot be considered for inventive step .... The technical part of the invention is thus essentially limited to instructing the server computer to apply the given conditions and perform any necessary calculations. ${ }^{179}$

The EPO's approach as evidenced in Hitachi, therefore, appears to be one in which the patentable subject matter requirement provides few obstacles to patentability, but which denies patent protection to subject matter which fails to demonstrate at least one "step" that is both inventive and technical. In a sense, it merely moves the relevant point of novelty inquiry from the patentable subject matter to the inventive step (obviousness) stage of the analysis. If the inventive step is one that can be performed by a human being, the invention fails the inventive step criterion. This approach clearly differs from the current U.S. approach, under which both patentable subject matter and nonobviousness (the latter in accordance with section 103 of the Patent Act) are considered with respect to the invention "as a whole," and not with respect to individual "steps" or elements. ${ }^{180}$ Incorporating this approach into U.S. law, however, might be difficult in light of the aforementioned language of section 103.

The works of Alan Durham and Dan Burk suggest two other possible point of novelty approaches. Durham ultimately recommends an approach that resembles the EPO's discarded contribution approach, under which

178. Id. ๆ $5.4,5.7$.

179. Id. $\lceil$ 5.7. The Board went on to state that, "if a step of a method has been designed in such a way as to be particularly suitable for being performed on a computer, it has arguably a technical character. Suggesting such a step might require technical considerations." Id. $\uparrow$ 5.8. But the Board nevertheless concluded that the subject matter at issue did not contain any feature "which does not correspond to what a human being would do if performing the auction without computer support." Id.

180. See 35 U.S.C. $\S 103$ (a) (2000). This section states:

A patent may not be obtained though the invention is not identically disclosed or described as set forth in section 102 of this title, if the difference between the subject matter sought to be patented and the prior art are such that the subject matter as a whole would have been obvious at the time the invention was made to a person having ordinary skill in the art.

Id. (emphasis added). 
one inquires whether the point of novelty or inventive step pertains to the technological arts, ${ }^{181}$ which Durham conceives as including software engineering. ${ }^{182}$ This approach would exclude inventions that couple standard programming techniques with non-technological steps, on the ground that "[a] patent claim that, in substance, describes only a non-technological advancement should be held beyond the scope of the 'useful arts,' even if it makes general references to existing technology." "Alternatively, if Burk is correct that we should be concerned about software patents that read on First Amendment-protected speech, perhaps an approach that requires the point of novelty to comprise something other than the software is preferable. ${ }^{184}$ Suppose, for example, that a claim comprises five elements, A, B, C, D, and E, where A, B, C, and D are prior art and E, the only point of novelty, necessarily reads on speech that is both functional and expressive and therefore, arguably, entitled to some degree of First Amendment protection. In such a case, a patent precludes others from engaging in otherwise lawful activity (practicing A, B, C, and D), based upon the content of the speech (E) that accompanies the activity. If Burk is right that much software is like $\mathrm{E}$, this result comes uncomfortably close to a content-based restriction on speech. To be sure, a patent might not preempt all uses of $\mathrm{E}$, but it would preempt otherwise lawful conduct when coupled with the performance of $E$. A point of novelty approach that focused on the non-software steps would preclude a patent in such a case, unless there was some other step $F$ that distinguished the invention from the prior art, in which case an injunction would not be based on the presence of $E$. In some instances this solution might be hard to square with the Durham proposal, however. A fruitful ground for future scholarly inquiry might center on the fundamental question of whether, or when, software patents embody elements such as the hypothetical " $E$ " that qualify as protected First Amendment speech. ${ }^{185}$

181. Cf. Durham, supra note 94, at 1518-19 (arguing that the problem with some inventions is that "the part that is new is not technological, and the part that is technological is not new," and that in such cases "[e]ither the black letter rules of patent law must give a little, or we must resign ourselves to patents on some essentially nontechnological inventions").

182. See id. at 1522-25.

183. Id. at 1525 .

184. Though possibly neither will accommodate the First Amendment interest sufficiently. Perhaps patent law needs a fair use doctrine, as Burk suggests. See Burk, supra note 133 , at $150-54$.

185. Burk himself is not sure that software should qualify as protected speech; he notes only that, in some contexts, courts have held that it is. See id. at 102 ("I believe the long-term implications of holding software to be protected speech could be more trouble- 
Professor Collins has proposed a reformulated mental steps doctrine that is structurally similar to the Durham and Burk proposals relating to technological arts. Under Collins' proposed version of the mental steps doctrine, an invention would be unpatentable if it met four criteria: (1) the claim recited "at least one act of information processing that can be performed by the human mind"; (2) the mental step is more than merely "a necessary accessory to real-world human action"; (3) the step is not merely one that recites an act of observation, but rather processes information; and (4) "the non-thought-based steps do not constitute a patentable method (and therefore are not a useful, novel and nonobvious method) in and of themselves." 186

Inversely, in a claim that does not propertize thought, any recited thought-based steps are technically superfluous steps in an otherwise valid claim that are added to make the utility of the claim more intuitively self-evident ... In these latter claims, the thought-based steps are harmless to the public because they do nothing more than restrict the scope of a patentee's rights to exclude. ${ }^{187}$

In addition to his proposal that is specific to the propertization of thought, the claim at issue in Metabolite would be unpatentable, because "the only recited non-thought based step in the claim," that is, the one involving assaying homocysteine, was known to the prior art. ${ }^{188}$ Collins argues that, because thought is often non-volitional, a claim that combines prior art with possibly non-volitional thought "may prevent the public from performing actions that, prior to the issuance of the patent, the public had the right to perform." ${ }^{189}$ Moreover, this approach might serve to vin-

some than the immediate folly such a holding might rectify."). His paper was published before the Supreme Court's decision in Eldred v. Ashcroft, however, and it might be useful to consider whether the Court's relative lack of concern over the effect of copyright extension on protected speech would translate into an analogous lack of concern in the patent realm - or not, given patent law's lack of equivalents to fair use or the idea/expression dichotomy.

186. Kevin Emerson Collins, Propertizing Thought, Syllogistic and Other, at 16-18, available at http://www.law.berkeley.edu/institutes/bclt/ipsc/papers2/Collins.doc; see also Collins, supra note 27, at 16-24.

187. Collins, supra note 186, at 18.

188. See id. at 19.

189. Id. at 27. Collins justifies his proposal in part on the ground that strict liability for claims that "propertize" reflexive thought, using his terminology, unconstitutionally removes subject matter from the public domain. See Collins, supra note 140, at 54-56. He therefore suggests that, in Metabolite, a third step consisting of "delivering a diagnosis of a B vitamin deficiency or a normal B vitamin level to the patient," might resolve the con- 
dicate personal autonomy interests by holding unpatentable inventions that otherwise would render conduct infringing merely because of the perhaps involuntary operation of the mind. ${ }^{190}$ As the Court of Customs and Patent Appeals suggested in an earlier time and place, "It is self-evident that thought is not patentable."

stitutional overbreadth problem. See id. at 69-70. The addition of the third step, however, would not cure the constitutional defects of the Metabolite claim if it is an interference with self-ownership interests that underlies the objection to the propertization of thought. See Collins, supra note 186, at 61-66.

190. Presumably the doctrine would not target so-called "ministerial" mental steps, such as merely observing a phenomenon, but rather only information-processing steps. See 1 CHISUM, supra note 17, $\S 1.03[6]$ [a] (noting that courts applying the mental steps distinguished between ministerial and evaluative mental steps); Collins, supra note 27 (manuscript at 16) (making a similar distinction).

191. In re Abrams, 188 F.2d 165, 168 (C.C.P.A. 1951). On balance, Collins' recommended reform to address the problem created by the confluence of strict liability and the reflexiveness of some acts of thinking would appear fairly modest in its effects. In terms of the Metabolite case, for example, the claim at issue would constitute patentable subject matter as long as some third element, such as "instructing the patient regarding the diagnosis of cobalamin deficiency" or "administering treatment for the deficiency" was added to the first two. See supra note 189. But if it would be easy to add such a step in most such cases, the reform makes no sweeping change to existing law. One might also note that patent owners are not likely to haul people into court for merely thinking. Someone who infringes the claim at issue in Metabolite by testing and then doing nothing more than making a mental correlation is unlikely to be detected. And even if he were detected, it is doubtful there would be any effective remedy for the infringement. What would be the benefit of an injunction, and what lost profits or royalties could be attributed to a merely mental correction? Hence there would be little incentive to sue. Looked at from the other direction, however, the modesty of the reform may be one of its virtues. Requiring the addition of a third step to claims such as the claim at issue in Metabolite would appear to have little disincentive effect upon medical research, if indeed the third step is easy to conceive and if few infringement claims would ever be premised upon purely mental correlations without more. Moreover, the reform would have the modest benefit of reducing the potential for unscrupulous or vindictive patent owners to use claims like the one at issue in Metabolite as a tool for harassment, by making clear that no one is even technically or theoretically liable for purely unavoidable behavior such as thinking. In an analogous context, a question under debate today is whether a real property owner is liable for infringement if a patented seed blows onto her property and begins propagating there, through no affirmative act whatsoever on the part of the real property owner. Patent infringement is a strict liability regime, to be sure, but arguably even strict liability usually contemplates some volitional act on the part of the alleged tortfeasor. If this latter line of reasoning is correct, however, it would also suggest that no one should be liable for the mere act of thinking, which is similarly often nonvolitional. See Collins, supra note 140, at 36-39 (distinguishing purposive and reflexive acts of thinking). In other words, I may have as little control over the memes that propagate within my brain as I do over the seeds that propagate within my real property. Finally, even if it would be rare for an infringement claim to be premised on the mere thinking of patentable thoughts, why 
In summary, if the technological arts and mental steps doctrines are to have even a modest impact, they may require the reintroduction of some sort of point of novelty test. Although the EPO's approach, which defers the relevant inquiry until the inventive step stage, may have much to recommend it, it is likely to be difficult to incorporate such a standard into U.S. law without amending section 103. By contrast, one could apply the approaches of Durham, Burk, and Collins at the subject matter stage, screening out inventions whose novelty and nonobviousness in relation to the prior art either (1) pertain to a non-technological art or (2) depend upon a step that can be performed mentally. Perhaps other commentators might further improve upon these proposals. Further, in the case of the Durham and Burk proposals, commentators would need to draw some conclusion as to whether an element comprising software is more like speech or engineering. All three proposals, however, might have the salubrious consequence of screening out patents that would otherwise intrude upon laws of nature and human liberty interests, while still permitting patent law to adapt to and accommodate new technology. In this respect, the proposals arguably preserve the wisdom of the older tradition without making a fetish of that tradition for its own sake.

\section{B. Physical Transformation Doctrine}

Reforming the physical transformation rule might be somewhat easier than reforming either the technological arts or mental steps rules. Judge Barrett's suggestion in Lundgren actually points the way to a plausible reconciliation of the autonomy principle with the principle that computerrelated art should not be arbitrarily excluded from the scope of patentable subject matter, even if it transforms nothing more than electric signals representing one form of data into signals representing another form of data. Recall that, under Judge Barrett's proposal, a process is patentable as long as it (1) is useful and (2) transforms matter or energy external to the human actor. ${ }^{192}$ This definition would recognize much computer-related art as patent eligible, but it would exclude what appear to be the most troubling patents from the standpoint of human liberty interests. Absent some compelling need to come close to invading these interests, which has yet to be demonstrated, a Burkean-inspired perspective on patent law might counsel against expanding patent protection to such non-traditional subject

should the state even theoretically be able to penalize its citizens for the content of their thoughts?

192. Ex parte Lundgren, 76 U.S.P.Q.2D 1385, 1399 (B.P.A.I. 2005) (Barrett, J., concurring in part and dissenting in part). 
matter, even if it remains agnostic or even supportive on the topic of the patentability of much computer-related art.

\section{CONCLUSION}

An optimist might say that the rise of the "useful, concrete, and tangible result" criterion, coupled with the concomitant abolition of the technological arts, mental steps, and physical transformation doctrines, is all part of the logical, orderly progression of patent law from some dim, archaic past. No longer will patentable subject matter be bound to arbitrary limitations. Any and all discoveries other than laws of nature, abstract ideas, and naturally occurring physical phenomena can and should be patented. In fact, let everything be patented, and the market will take care of the rest. Anything less threatens to stem the rising tide of innovation and progress.

But this rosy scenario should give us pause. Patents are an integral part of the U.S. economy, but there is no evidence that extending patent protection into every corner of human activity would bring positive returns. Further, there is potentially much to lose. What will likely disappear in the transition to an "anything goes" system are some of the less quantifiable, but real, benefits of a patent system that is more humble in its aspirations. These include potential losses to freedom of speech, personal autonomy, and other liberty interests that are compromised when virtually any human activity, including involuntary mental processes, can intrude upon someone else's patent rights. Some of the traditional doctrines of patent law may have embodied latent liberty-preserving wisdom that we discard at our peril.

Edmund Burke concluded his Reflections on the Revolution in France by describing himself as someone who, "when the equipoise of the vessel in which he sails may be endangered by overloading it upon one side, is desirous of carrying the small weight of his reasons to that which may preserve its equipoise." 193 Contemporary patent law can be an enormous force for good, but it too is arguably in danger of losing its equipoise. I have argued herein that, in pursuit of a rational, orderly system under which virtually anything constitutes patentable subject matter, patent law has cast overboard traditional limiting doctrines that silently assisted in the preservation of liberty and other human interests. Respect for the wisdom of the past may not appear as satisfying as the imposition upon messy reality of some rational, orderly, all-encompassing plan-whether symbolized by words such as "Liberté, Égalité, Fraternité," or "Useful, Concrete, and

193. BURKE, supra note 3, at 210. 
Tangible"- but restraint and moderation may be wiser in the longer run. Naive as it may sound to our jaded modern ears, perhaps we would be better off accepting some of those so-called "self-evident" truths ${ }^{194}$ as selfevident after all. Vive l'ancien régime. 